\title{
HIBRIDAÇÃO SOMÁTICA ENTRE TANGERINA 'CLEÓPATRA' E LARANJA 'AZEDA' POR FUSÃO DE PROTOPLASTOS
}

\author{
VAGNER AUGUSTO BENEDITO
}

Engenheiro Agrônomo

Orientador: Prof. Dr. FRANCISCO DE ASSIS ALVES MOURÃO FILHO

Dissertação apresentada à Escola Superior de Agricultura "Luiz de Queiroz", Universidade de São Paulo, para obtenção do título de Mestre em Agronomia, Área de Concentração: Fitotecnia.

PIRACICABA

Estado de São Paulo

Maio - 1999 


\section{Dados Internacionais de Catalogação na Publicação (CIP) DIVISÃo DE BIBLIOTECA E DOCUMENTAÇÃO - Campus "Luiz de Queiroz"/USP}

\section{Benedito, Vagner Augusto}

Hibridação somática entre tangerina Cleópatra e laranja "Azeda"por fusão de protoplastos / Vagner Augusto Benedito. - - Piracicaba, 1999.

$$
62 \text { p. : il. }
$$

Dissertação (mestrado) - - Escola Superior de Agricultura Luiz de Queiroz, 1999. Bibliografia.

1. Calo embriogênico 2. Embriogênese somática 3. Fruta cítrica 4. Fusăo de protoplasto 5 . Hibridação somática 6 . Melhoramento genético vegetal 7. Portaenxerto 8 . Variedade 1. Titulo

CDD 634.31 
"Eu seil, Semhor Deus, que não pertence ao homem o seu caminho, que não é dado ao homem que caminha dirigir seus passos"

Jeremias, 10,23 


\section{AGRADECIMENTOS}

Ao Deus vivente e reinante, Senhor da minha História, toda a honra e toda a glória.

À minha mãe, pelo carinho e incentivo prestados durante a vida inteira.

Ao meu orientador,.Prof. Dr. Francisco de Assis, Alves Mourão Filho, por tudo o que ensinou-me.

Àqueles que me assistiram durante todo o tempo: dona Rita, Terezinha, Tadeu, Chico, Daniel, Expedito, Bento, minha eterna gratidão.

Aos inesquecíveis amigos, Vagner Aleixo, Marilia Santos Silva, Maria Eloísa Salustiano, Jaques Ribeiro Bom, Francine Lorena Cuquel, Maria Angélica Costa, Márcio Leandro Tomaz, Pe. Thiago por todas as enaltecedoras horas que passamos juntos e partilhamos nossas vidas.

Às professoras Beatriz M. Januzzi Mendes, Adriana P. M. Rodrigues e Maria Tereza Derbyshire, pelo auxílio no desenvolvimento do trabalho e da minha vida.

A todos os colegas dos laboratórios de Biotecnologia de Plantas Hortícolas e Biotecnologia Vegetal, por todo apoio recebido.

Ao laboratorista Carlos Alberto de Oliveira, pela sua competência e solicitude. Ao Prof. Raymond S. Pacovsky pela disponibilidade e humanidade.

A todos do Departamento de Produção Vegetal, sempre presentes e solícitos a todo o momento. 


\section{SUMÁRIO}

Página

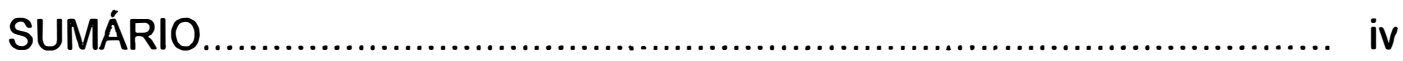

LISTA DE FIGURAS................................................................ vii

LISTA DE TABELA ....................................................................... viii

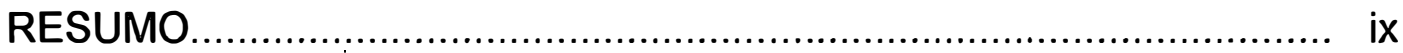

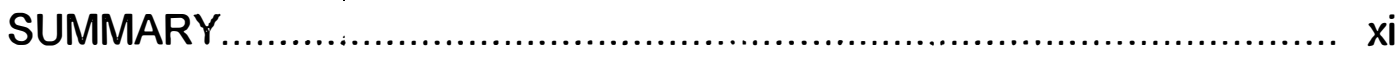

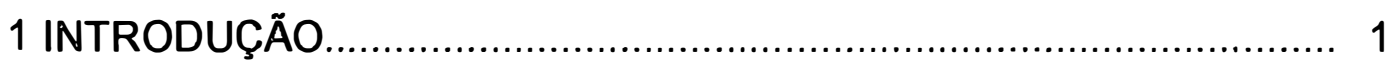

2 REVISÃO DE LITERATURA ................................................... 3

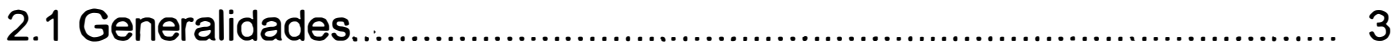

2.1.1 Cultura de calos embriogênicos............................................... 4

2.1.2 Cultura de células em suspensão............................................. 5

2.2. Hibridação somática em citros...................................................... 5

2.2.1 Isolamento de protoplastos......................................................... 7

2.2.2 Fusão de protoplastos.............................................................. 9

2.2.3 Embriogênese somática...................................................... 12

2.2.4 Confirmação da hibridação somática...................................... 14

2.3 Considerações finais.................................................................. 15

3 CALOGÊNESE, EMBRIOGÊNESE SOMÁTICA E ISOLAMENTO DE PROTOPLASTOS EM VARIEDADES DE LARANJA DOCE (Citrus sinensis L. Osbeck) ............................................................... 16

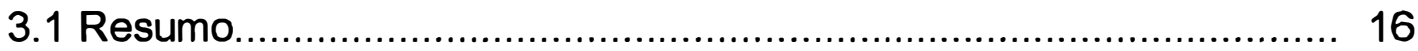

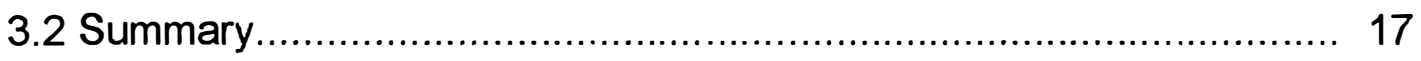

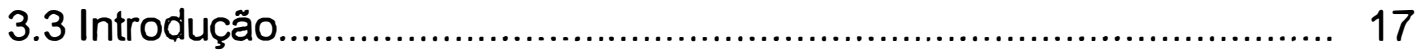


3.4 Material e Métodos................................................................. 19

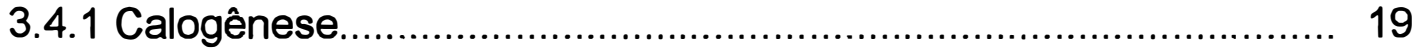

3.4.2 Embriogênese somática....................................................... 20

3.4.3 Isolamento de protoplastos.................................................... 21

3.5 Resultados e Discussão................................................................. 22

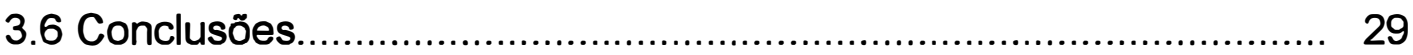

4 HIBRIDAÇÃO SOMÁTICA ENTRE TANGERINA 'CLEÓPATRA'

(Citrus reshni Hort. Ex Tanaka) E LARANJA 'AZEDA' (Citrus aurantium

L.) POR FUSÃO DE PROTOPLASTOS ......................................... 30

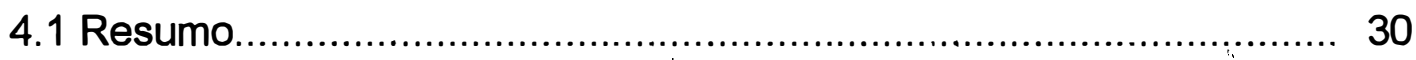

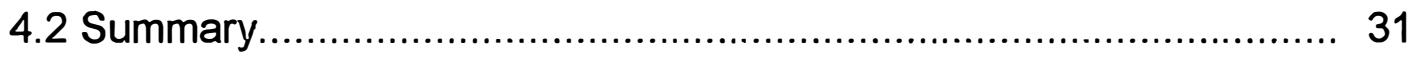

4.3 Introdução.............................................................................. 31

4.4 Material e Métodos................................................................. 33

4.4.1 Material vegetal........................................................... 33

4.4 .2 Isolamento e purificação dos protoplastos................................... 33

4.4.3 Fusão e cultivo dos protoplastos e regeneração de plantas.......... 34

4.4.4 Confirmação da hibridação somática........................................... 35

4.4.4.1 Análise da morfologia foliar.................................................. 35

4.4.4.2 Análise molecular via RAPD............................................. 36

4.4.4.2.1 Extração de DNA ................................................................. 36

4.4.4.2.2 Reação de amplificação do DNA........................................ 37

4.4.4.2.3 Eletroforese e análise...................................................... 37

4.5 Resultados e Discussão................................................................ 38

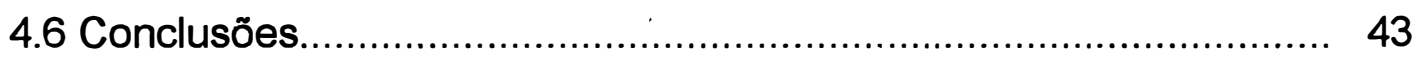


5 CONCLUSÕES.................................................................. 44

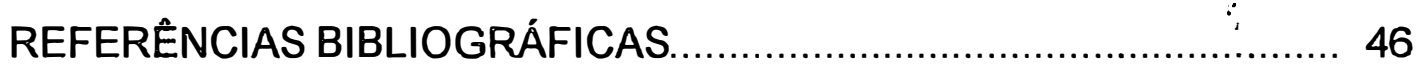




\section{LISTA DE FIGURAS}

Página

1 Embriões somáticos originando-se a partir de calo embriogênico de laranja 'Rubi'.

2 Eficiência de isolamento de protoplastos de calos embriogênicos de citros.

3 Fusão de protoplastos a partir de mesofilo de laranja 'Azeda' e calo embriogênico de tangerina 'Cleópatra'.

4 Híbrido somático de tangerina 'Cleópatra' e laranja 'Azeda' obtidos por fusão de protoplastos

5 Padrões de RAPD do híbrido somático e seus parentais. 


\section{LISTA DE TABELAS}

Página

1 Calogênese a partir de óvulos abortados de variedades de laranja doce.

2 Embriogênese somática de calos de variedades de laranja doce em resposta ao tipo e à concentração de carboidratos adicionados ao meio de cultivo, após 4 semanas de incubação. 


\title{
HIBRIDAÇÃO SOMÁTICA ENTRE TANGERINA 'CLEÓPATRA' ( Citrus reshni Hort. Ex Tanaka) E LARANJA 'AZEDA' (Citrus aurantium L.) POR FUSÃO DE PROTOPLASTOS
}

\author{
Autor: Vagner Augusto Benedito \\ Orientador: Prof. Dr. Francisco de Assis Alves Mourão Filho
}

\section{RESUMO}

O principal objetivo deste trabalho foi a obtenção de plantas híbridas somáticas entre tangerina 'Cleópatra' (Citrus reshni Hort. Ex Tanaka) e laranja 'Azeda' (Citrus aurantium L.) como apoio ao desenvolvimento de novas variedades de porta-enxerto de citros. Dada a complementariedade das características dos dois parentais utilizados, espera-se que este híbrido seja uma alternativa para a diversificação dos pomares cítricos. Este novo genótipo tem o potencial de apresentar qualidades desejadas num porta-enxerto, como a tolerância ou resistência ao declínio, ao vírus da tristeza, ao frio e à seca, a boa produtividade e a boa qualidade de frutos, além de induzir um menor porte na planta. Paralelamente, estudou-se também a indução de calos embriogênicos a 
partir de óvulos abortados de frutos maduros de seis variedades de laranja doce (Citrus sinensis L. Osbeck). A embriogênese somática e o isolamento de protoplastos também foram estudados a partir dos calos obtidos. Observou-se um grande efeito do genótipo em todos os experimentos realizados, embora a galactose mostrou-se eficiente para a maioria das variedades na indução à embriogênese e a solução enzimática composta por $1 \%$ celulase, $1 \%$ macerase e $0,2 \%$ pectoliase mostrou-se bastante adequada para as variedades de laranja doce. 


\title{
SOMATIC HYBRIDIZATION OF 'CLEOPATRA' MANDARIN (Citrus reshni Hort. Ex Tanaka) AND SOUR ORANGE (Citrus aurantium L.) VIA PROTOPLAST FUSION
}

\author{
Author: Vagner Augusto Benedito \\ Adviser: Prof. Dr. Francisco de Assis Alves Mourão Filho
}

\section{SUMMARY}

The aim of this research was to obtain somatic hybrids between 'Cleopatra' mandarin (Citrus reshni Hort. Ex Tanaka) and sour orange (Citrus aurantium L.) as a means of developing new citrus rootstocks. Due to trait complementary in both parental this hybrid may be an alternative to citrus diversification. This somatic hybrid has the potential to show desired qualities as a rootstock, such as tolerance or resistence to citrus blight, tristeza virus, cold and drought, a high quantity yield, a high quality fruit and reduce the tree size. At the same time, embryogenic callus induction from aborted ovules from sweet orange (Citrus sinensis L. Osbeck) ripe fruits, six varieties was investigated. Also, somatic embryogenesis and protoplast isolation were studied from the calli 
that were formed. There is a wide genotype effect in all experiments, in spite of the fact that galactose was quite efficient for the majority of varieties in embryogenesis induction and the enzymatic solution composed by $1 \%$ cellulase, $1 \%$ macerase and $0,2 \%$ pectolyase was very adequate for sweet orange varieties. 


\section{INTRODUÇÃO}

Dentre as frutíferas, a cultura dos citros tem lugar de destaque no âmbito nacional e internacional. Segundo a FAO (1999), a produção de citros no mundo ficou acima de 102 milhões de toneladas métricas na safra 97/98, tendo - Brasil participado com mais de 24 milhões de toneladas métricas. A importância do Brasil como produtor de citros está embasada principalmente na laranja, cuja produção foi estimada, para a safra de 97/98, em mais de 23 milhões de toneladas. O Estado de São Paulo participou, na safra citada, com mais de $83 \%$ da produção total de laranja, constituindo-se o principal Estado produtor e processador desta fruta no país (FNP Consultoria e Comércio, 1999).

A despeito da grande importância da citricultura no Brasil, o melhoramento genético dos citros não tem alcançado grandes avanços, encontrando-se poucas variedades comerciais no Brasil, tanto para copa como porta-enxerto. Esta estreita base genética reflete um risco do qual já fomos vítimas no início do século: o assolamento da cultura por patógenos até então exóticos. Percebe-se a necessidade do melhoramento vegetal atuar nesta cultura, criando mais variedades para a diversificação dos pomares. Isto não é uma tarefa fácil, dadas as características inerentes à biologia dos citros, ou seja, os fatores relacionados intrinsicamente à complexa biologia reprodutiva da planta, tais como o longo período de juvenilidade, a presença de embriões nucelares (poliembrionia), incompatibilidade e esterilidade sexual, alta heterozigosidade, além do pouco conhecimento sobre a herança de muitas características de interesse agronômico, comprometendo, desta forma, o melhoramento convencional da cultura (Soost \& Cameron, 1975). 
Com a advento de novas técnicas biotecnológicas abriu-se, então, expectativas para o melhoramento de citros e de outras culturas frutícolas que também apresentam dificuldades neste campo. A técnica de fusão de protoplastos tem sido utilizada para a produção de muitos híbridos somáticos de citros, tendo estes, grande potencial para o melhoramento de variedades tanto para copa quanto para porta-enxerto (Grosser, 1993). As pesquisas sobre protoplastos abriram amplas possibilidades para o melhoramento genético das espécies cítricas. Logo, a fusão de protoplastos tem se tornado um poderoso recurso na combinação de genótipos de citros para a produção de auto e alotetraplóides, gerando fontes de parentais para o melhoramento clássico de citros (Louzada et al., 1992).

Almejando colaborar com o melhoramento de citros via fusão de protoplastos, este trabalho objetivou a produção de calos embriogênicos para serem fontes de protoplastos, o estudo da embriogênese somática, o isolamento de protoplastos e a hibridação somática entre protoplastos para produção de um novo genótipo com potencial para uso como variedade de porta-enxerto de citros. 


\section{REVISÃO DE LITERATURA}

\subsection{Generalidades}

As técnicas in vitro fornecem estratégias para o desenvolvimento agrícola e o melhoramento de plantas através de métodos seletivos, modificações genéticas, micropropagação e indução a mutações (Reddy et al., 1989).

O termo 'cultura de tecidos e células' refere-se às técnicas de excisão, desinfestação e cultivo, em meio nutritivo, de células, tecidos ou órgãos vegetais, em condições assépticas (Torres et al., 1998). Suas técnicas possibilitam a obtenção e o cultivo de híbridos ou novas variedades que não são possíveis pelos métodos tradicionais (Reddy et al., 1989).

A aplicação das técnicas de cultura de tecidos no melhoramento de plantas podem ser apontadas como a conservação e a avaliação do germoplasma, o aumento da variabilidade genética com o fim de selecionar variantes superiores, introgressão de genes de interesse (polinização in vitro, cultura de embriões, fusão de protoplastos e cultura de anteras), além da aceleração de programas de melhoramento convencional, via germinação de sementes e cultura de frutos in vitro, clonagem de genótipos e limpeza clonal (Ferreira et al., 1998).

A manipulação de protoplastos exige o domínio das técnicas mais refinadas da cultura de tecidos, pois parte de uma única célula desprovida de parede celular e espera-se a regeneração de uma planta completa. 


\subsubsection{Cultura de calos embriogênicos}

Os calos embriogênicos são importantes no processo de hibridação somática por serem fontes embriogênicas de protoplastos, uma vez que o mesofilo fornece protoplastos inçapazes de regenerar plantas nas condições de cultivo utilizadas ( Jiménez, 1996).

O primeiro relato bem sucedido de indução de calos a partir de tecidos nucelares de citros foi feito por Kochba et al. (1972), cultivando óvulos imaturos da variedade de laranja doce 'Shamouti'. Embora os tecidos nucelares sejam os explantes mais utilizados para a obtenção de calos embriogênicos, também encontra-se sucesso em trabalhos com óvulos não desenvolvidos de frutos maduros (Kochba et al., 1972; Vardi et al., 1982; Ling et al., 1990; Kunitake et al., 1991), de embriões adventícios (Vardi et al., 1986) e da região do hipocótilo de embriōes (Hidaka \& Kajiura, 1988; Ling et al., 1989).

A calogênese a partir de tecidos diferenciados, exige previamente uma desdiferenciação celular, sendo que os principais fatores que atuam neste processo são descritos por Moore (1985) como o genótipo, a idade do explante, as condições do ambiente incidentes sobre a planta doadora, o meio e as condições de cultivo. $\mathrm{O}$ meio de cultivo mais amplamente difundido para a indução e o cultivo dos calos embriogênicos é o meio MT (Murashige \& Tucker, 1969), com $50 \mathrm{~g} \cdot \mathrm{L}^{-1}$ de sacarose e a adição de $500 \mathrm{mg} \cdot \mathrm{L}^{-1}$ de extrato de malte (Oliveira, 1994; Kochba \& Spiegel-Roy, 1973).

Alguns reguladores de crescimento são utilizados por pesquisadores para a indução da calogênese. Os principais reguladores empregados são: 6benzilaminopurina ou benziladenina (BAP ou BA), nas concentrações até 10 mg. L $^{-1}$ (Saito et al., 1991, 1993; Oliveira, 1994), cinetina (KIN) (Hidaka, 1995) e ácido indolilacético (AIA) (Oliveira, 1994). Entretanto, muitas vezes a calogênese é conseguida sem a adição destes reguladores. 


\subsubsection{Cultura de células em suspensão}

Cid (1998) relata que a suspensão celular destina-se à obtenção e a proliferação de células em meio líquido, sob agitação contínua, evitando-se, assim, formação de gradientes nutricionais e gasosos no meio de cultivo.

A partir de calos embriogênicos e friáveis pode-se iniciar facilmente o cultivo de suspensões celulares, uma vez que a composição do calo possibilita que o tecido desagregue-se no meio líquido em agitação (Jiménez, 1996).

Os meios de cultivo mais amplamente utilizados para citros são o meio MT (Murashige \& Tucker, 1969) modificado (com $500 \mathrm{mg} . \mathrm{L}^{-1}$ de extrato de malte e 50 g. $\mathrm{L}^{-1}$ de sacarose) e o H + H (Grosser \& Gmitter Junior, 1990a; Deng et al., 1992), sob agitação orbital constante de $100 \mathrm{rpm}$. O tempo de repicagem mais utilizado é de 2 semanas (Sim et al., 1988; Grosser \& Gmitter Junior, 1990a; Deng et al., 1992). O cultivo dá-se geralmente na ausência de luz, em temperatura de cerca de $27^{\circ} \mathrm{C}$.

Devido a alta taxa de multiplicação celular, uma das suas principais vantagens em relação aos calos cultivados em meio sólido, pode-se observar um alto índice de variação somaclonal (Cid, 1998), o que pode tornar-se preocupante, dependendo do objetivo do trabalho.

As células em suspensão, juntamente com os calos friáveis, são tidas como as melhores fontes com capacidade embriogênica para o isolamento de protoplastos de citros (Grosser \& Gmitter Junior, 1990a).

\subsection{Hibridação somática em ciţros}

A hibridação somática de protoplastos de plantas é uma técnica através da qual as propriedades celulares podem ser modificadas mediante fusões nucleares ou citoplasmáticas (Carneiro et al., 1998). 
A hibridação somática tem vantagens sobre a hibridação sexual para o melhoramento de citros, pois permite combinar parentais com características complementares; sem perda significante do vigor, resultando na expressão aditiva das características dominantes nos híbridos (Grosser \& Gmitter Junior 1990a). Este é um processo aditivo que combina os genomas nucleares completos de ambos os parentais, podendo, entretanto, nas combinações entre espécies mais distantes, ocorrer a eliminação cromossômica. A heterozigose potencial dos híbridos somáticos é grande, dependendo das diferenças dos alelos dos parentais. Em contraste à hibridação sexual, em que a herança citoplasmática é predominantemente maternal, os híbridos somáticos permitem a contribuição de ambos os parentais (Grosser \& Gmitter Junior, 1990b).

Segundo Grosser (1993) duas estratégias podem ser utilizadas para a aplicação da tecnologia de hibridação somática nos programas de melhoramento de porta-enxerto. A primeira visa produzir híbridos somáticos que combinem genótipos complementares de variedades de porta-enxerto. Uma segunda estratégia é a hibridação de espécies incompativeis sęxualmente de gêneros relacionados que possuam características de interesse agronômico.

Programas de melhoramento de copa lambém podem beneficiar-se da hibridação somática, combinando variedades as quais o melhoramento convencional é inibido por esterilidade de pólen, poliembrionia e baixa produção de sementes, como laranja 'Navel' e tangerina 'Satsuma' (Kobayashi et al., 1988b). O mais importante papel da hibridação somática nos programas de melhoramento de copa é, no entanto, a produção de híbridos somáticos tetraplóides $(2 n=4 x=36$ cromossomos) que possam ser utilizados como parentais em cruzamentos sexuais interploidais com plantas diplóides $(2 n=2 x$ $=18$ cromossomos), produzindo uma progênie triplóide ( $3 x=27$ cromossomos). As plantas cítricas triplóides não produzem sementes, devido o número ímpar de cromossomos interferir na meiose, inibindo, desta forma, o desenvolvimento da semente. A produção de variedades que produzam frutos para mesa sem 
sementes é um importante objetivo da maioria dos programas de melhoramento de copa (Grosser, 1993). A fertilidade de um híbrido somático intergenérico da família Rutaceae foi pesquisada por Kobayashi et al. (1991b), concluindo-se que o híbrido entre laranja 'Trovita' (Citrus sinensis) e Poncirus trifoliata obtido por fusão de protoplastos tinha fertilidade masculina e feminina.

Assim, a hibridação somática pode propiciar uma forma de utilizar clones estéreis nos esquemas de melhoramento, ou de transpor incompatibilidades de cruzamento na criação de formas híbridas, previamente impossíveis entre espécies e gêneros.

Entretanto, a aplicação da tecnologia da hibridação somática de citros requer a otimização das técnicas de cultura de tecidos e células, assim como o conhecimento das características horticulturais das variedades empregadas.

\subsubsection{Isolamento de protoplastos}

Protoplastos são células vegetais destituídas da parede celular. Sendo obtidos em laboratórios, pela retirada mecânica ou enzimática da parede celulósica, são considerados como um estado transitório das células (Carneiro et al., 1998).

A manipulação dos protoplastos e a sua regeneração até plantas é considerada uma ferramenta inovadora nos programas de melhoramento genético, podendo ser utilizados na fusão de protoplastos, transformação de plantas e indução de variação somaclonal, além de servirem para estudos básicos nas áreas de bioquímica, fisiologia vegetal e genética.

Klercker $^{1}$ (1892), citado por Carneiro et al. (1998), foi quem conseguiu isolar os primeiros protoplastos através do método mecânico. Este feito,

\footnotetext{
${ }^{1}$ KLERCKER, J. A. Eine methode sur isolierung labender protoplasten. Swenka. Vex'Akad Forh Stockholm, v.9, p.463-471, 1892.
} 
entretanto, não deu o impulso necessário à tecnologia de protoplasto, devido a baixa eficiência da técnica. Cocking (1960), entretanto, ao trabalhar com enzimas celulolíticas no isolamento de protoplastos, aumentou sobremaneira a eficiência da metodologia que abriu perspectivas para seu uso na biologia e, posteriormente, no melhoramento de plantas.

Celulose, hemicelulose e pectina são os principais constituintes da parede celular dos vegetais. Outrossim, a composição da parede celular é variável entre as espécies, variedades, tecidos e condições de cultivo, requerendo um sistema enzimático específico para a sua digestão (Carneiro et al., 1998; Ochatt \& Power, 1992).

As enzimas mais utilizadas na maceração enzimática para a obtenção de protoplastos vegetais são as celulases [Driselase (Kyowa Hakko, Plenum Scientific), Cellulysin Onozuka R-10 (Calbiochem) e Cellulase (Sigma)], hemicelulases [Rhozyme HP 150 (Corning Glass) e Hemicellulase (Sigma)] e pectinases [Macerozyme (Calbiochem), Pectinol AC (Corning. Glass), Pectolyase Y-23 (Kikkoman Shoyu), Pectinase (Sigma) e PATE (Hoechst)] (Evans \& Bravo, 1983).

Uma vez que a principal função da parede celular é proteger as células contra danos fisiológicos, os protoplastos estão altamente vulneráveis à mudança no potencial osmótico do meio circundante (Fungaro \& Vieira, 1989). A estabilização osmótica geralmente é alcançada pela adição de agentes osmóticos aos meio de cultivo, especialmente o sorbitol, manitol e sacarose (Carneiro et al., 1998). O principal meio de cultivo para protoplastos de citros é - $\mathrm{BH}_{3}$, em concentrações de manitol variando de 0,6 a 0,7 M (Grosser \& Gmitter Junior, 1990a; Mourão Filho, 1995; Mendes-da-Glória, 1998).

Protoplastos cítricos podem ser obtidos de vários tecidos, incluindo-se folhas, calos não embriogênicos, tétrades florais, calos embriogênicos e células em suspensão (Grosser \& Chandler, 1987; Grosser \& Gmitter Junior, 1990b), 
sendo estes últimos as fontes mais adequadas para a obtenção de protoplastos com capacidade embriogênica.

Em citros, o primeiro isolamento de protoplastos com capacidade embriogênica foi realizado por Vardi et al. (1975), utilizando-se como explante calo embriogênico de laranja doce 'Shamouti'. Os melhores resultados para o isolamento de protoplastos de citros têm sido obtidos de calos friáveis com baixo conteúdo de amido e, especialmente, de suspensões celulares (Grosser, 1994; Kobayashi et al., 1985). Para o isolamento de material foliar, tem-se obtido melhores resultados com folhas oriundas de plântulas nucelares cultivadas in vitro, por eliminar o processo de desinfestação antes do isolamento. Pode-se, entretanto, utilizar folhas provenientes plantas provenientes de câmaras de crescimento, casa de vegetação ou, até mesmo, do campo (Jiménez, 1996).

Diferentemente dos protoplastos obtidos de calos friáveis e suspensões celulares, os protoplastos de folhas de citros não são capazes de regenerar em meio de cultivo desprovido de reguladores de crescimento (Jiménez, 1996).

\subsubsection{Fusão de protoplastos}

O aspecto mais significante da fusão de protoplastos na biotecnologia vegetal e na biologia celular é a possibilidade da produção de combinações núcleo-citoplasmáticas que são difíceis, ou mesmo impossíveis, de serem obtidas nos cruzamentos sexuais convencionais (Morikawa \& Yamada, 1992). A ausência da parede celular possibilita, sob certas condições, que dois ou mais protoplastos em contato fiquem aderidos e, sob um estímulo apropriado, fundam-se (Jiménez, 1996).

Os métodos mais utilizados para induzir fusões de protoplastos consistem no tratamento com polietilenoglicol (PEG) em condições salinas (Kao \& Michayluk, 1974) e na aplicação de correntes elétricas, ou seja, a eletrofusão 
(Zimmermann \& Scheurich, 1981 e Zimmermann, 1982), embora outros métodos também já tenham sido empregados, como tratamentos com nitrato de sódio, proteínas de agregação (como o colágeno), íons cálcio em meio alcalino e métodos imunológicos (Bajaj, 1994).

O primeiro exemplo de hibridação somática em citros foi descrito por Ohgawara et al. (1985), sendo produto intergenérico (Poncirus trifoliata + Citrus sinensis cv. 'Trovita'), com o uso de PEG. O primeiro híbrido interespecífico foi produzido entre laranja doce (C. sinensis cv. 'Washington') e tangerina Satsuma (C. unshiu cv. 'Hayashi') (Kobayashi et al., 1988b).

Dentre os vários pesquisadores que estudam a cultura, fusão de protoplastos e regeneração de plantas cítricas a partir destes, destacam-se Grosser e equipe (Grosser, 1993, 1994; Grosser \& Chandler, 1987; Grosser \& Gmitter Junior, 1990a, 1990b; Grosser et al., 1988a, 1988b, 1989, 1990, 1992a, 1992b, 1994, 1996, 1998a, 1998b ), Vardi e equipe (Vardi \& Galun, 1988, 1989; Vardi et al., 1975, 1982, 1986, 1987, 1989, 1990), Kobayashi e equipe. (Kobayashi \& Ohgawara, 1988; Kobayashi et al., 1983, 1984, 1985, 1988a, 1988b, 1991a, 1991b, 1995), Ohgawara e equipe. (Ohgawara et al., 1985, 1989, 1991), Hidaka (Hidaka, 1995; Hidaka \& Kajiura, 1988; Hidaka \& Omura, 1992) e Mourão Filho e equipe (Mourão Filho, 1995; Mourão Filho \& Grosser, 1992; Mourão Filho et al., 1994a, 1994b, 1996). O Brasil, apenas recentemente está trabalhando com protoplastos de citros, sendo os dois primeiros híbridos somáticos produzidos por Mendes-da-Glória (1998) e Latado (1998).

Exemplos destas pesquisas em variedades de copa são: lima 'Key' + laranja 'Valência'(Grosser et al., 1989); híbrido de tangerina 'Clementina' e tangelo 'Orlando' + laranja 'Succari', laranja 'Hamlin' + tangerina 'Dancy' (Grosser et al., 1992a); laranja 'Hamlin' + limão 'Rugoso', laranja 'Valência' + limão 'Rugoso', pomelo 'Thompson' + tangor 'Murcote' (Grosser et al., 1992b); laranja 'Navel' + tangor 'Murcote' (Kobayashi et al., 1988a); laranja 'Navel' + tangerina 'Satsuma' (Kobayashi et al., 1988b); laranja 'Navel' + tangor 'Murcote' 
(Kobayashi et al., 1991a); tangerina Satsuma + laranja 'Navel', pomelo + laranja 'Navel' (Kobayashi et al., 1995); laranja 'Trovita' e laranja 'Navel' + tangerina 'Satsuma', citrange 'Troyer' e tangor 'Murcote' (Kobayashi \& Ohgawara, 1988); laranja 'Navel' + pomelo 'Marsh' (Ohgawara et al., 1989); laranja 'Navel' + citrange 'Troyer' (Ohgawara et al., 1991); laranja 'Succari' + tangerina 'Dancy', tangelo 'Mineola', tangor 'Murcote', tangelo 'Page' e tangerina 'Ponkan' (Mourão Filho et al., 1996); tangelo 'Seminole' + limão 'Lisboa' e limão 'Rugoso' (Moriguchi et al., 1996); tangerina 'Satsuma' + limão 'Rugoso' e yuzu (Hidaka \& Omura, 1992); limão 'Femminello' + laranja 'Hamlin' e limão 'Milan' (Tusa et al., 1992).

Combinações com potencial para porta-enxerto são citadas a seguir: $F$. crassifolia + laranja 'Valência' (Deng et al., 1992); laranja 'Hamlin' + limão 'Rugoso', laranja 'Valência' + Fortunella crassifolia e Citrus ichangensis, tangor 'Murcote' + limão 'Messina' (Deng et al., 1995); laranja 'Valência' + limão 'Femminello' (Tusa et al., 1990); limão 'Rugoso' + tangerinas 'Ponkan' e 'Hazzara' (Morigushi et al., 1996); limão 'Rugoso' + laranja 'Hamlin' e 'Valência', tangerina 'Cleópatra' + citrumelo 'Swingle' e Poncirus trifoliata (Grosser et al., 1992b); tangerina 'Cleópatra' $+P$. trifoliata ', laranja 'Succari' $+P$. trifoliata, laranja 'Azeda' + $P$. trifoliata e limão 'Cravo', limão 'Milan' + tangerina 'Sun Chu Sha' (Grosser et al., 1994); laranja Azeda 'Keen' + tangerina 'Cleópatra' e Citrus microcarpa (Grosser et al., 1996); laranja 'Hamlin' + limão 'Cravo', laranja 'Azeda' + limão 'Volkameriano', híbrido de laranja 'Azeda' + limão 'Cravo', laranja 'Valência' + citrange 'Carrizo' (Louzada et al., 1992); laranja 'Succari' + tangerinas 'Dancy' e 'Pokan', tangelos 'Mineola' e 'Page' (Mourão et al., 1996); Poncirus trifoliata + Fortunella hindsii (Miranda et al., 1997). 


\subsubsection{Embriogênese somática}

Um sistema eficiente de regeneração de plantas a partir de culturas de tecidos ou células é reconhecidamente uma coṇdição essencial para a aplicação das modernas técnicas de melhoramento vegetal (Litz \& Gray, 1992).

A embriogênese somática tem um grande potencial na propagação clonal de espécies horticulturais e a cultura de células embriogênicas é um material promissor para a cultura de protoplastos, a hibridação somática e a transformação genética (Kunitake \& Mii, 1995).

Pode-se definir embriogênese somática como o processo pelo qual células somáticas desenvolvem-se em plantas através de estádios embriológicos característicos, sem a fusão dos gametas (Williams \& Maheswaran, 1986; Yeung, 1995). O embrião somático, assim, passa pelas fases globular, coração, torpedo e cotiledonar, embora nem sempre sejam vistas todas as fases durante seu desenvolvimento (A. P. M. Rodriguez, comunicação pessoal). Entre as diferenças dos embriões somáticos e zigóticos citam-se o desenvolvimento livre de correlações físicas, fisiológicas e genéticas do embrião somático, as quais ocorrem durante o desenvolvimento de um embrião zigótico (Zimmermann, 1993), ainda, os embriões somáticos apresentam um sistema vascular fechado, sem conexão com os tecidos adjacentes do explante inicial (Guerra et al., 1998). Apesar dos embriões somáticos serem originados de células somáticas, sua semelhança com os embriões zigóticos leva a presumir que resultem da expressão gênica que regula a mesma via de desenvolvimento (Parrot et al., 1991).

Tem-se reconhecido que a embriogênse somática é a melhor via de regeneração induzida pela cultura de tecidos in vitro, ocorrendo indiretamente a partir de calos, suspensão celular ou cultura de protoplastos, ou diretamente de células de tecidos com estrutura organizada (Williams \& Maheswaran, 1986). 
Entretanto, a embriogênese somática a partir de calos tem se mostrado, muitas vezes, limitante ao processo do melhoramento genético de citros e tem sido alvo de intensas pesquisas, com o intuito de maximizar a produção de plantas oriundas ou não de fusão de protoplastos (Kunitake \& Mii, 1995).

O efeito de diversas substâncias na embriogênese de calos cítricos tem sido amplamente estudado. A embriogênese somática em citros foi inibida por ácido giberélico (Kochba et al., 1978), citocinina (Kochba \& Spiegel-Roy, 1977; Kobayashi et al., 1984) e auxina (Kochba \& Spiegel-Roy, 1977). Como promotores da embriogênese foram encontrados extrato de malte, adenina (Kochba \& Spiegel-Roy, 1973), ethephon e ácido abscísico (ABA) (Kochba \& Spiegel-Roy, 1977). Inibidores da biossíntese de $\mathrm{GA}_{3}$, bem como anti-auxinas e anti-citocininas promoveram o desenvolvimento de embriões nucelares (Kochba \& Spiegel-Roy, 1977; Kochba et al., 1978). Os resultados alcançados com citros diferente do que é encontrado para as outras espécies em geral, as quais tem o processo embriogênico induzido por auxinas fortes (Dejong, 1993). Isto pode ser explicado considerando-se que os calos embriogênicos de citros já possuem um nível interno elevado de auxinas responsável pela sua competência embriogênica (Epstein et al., 1977).

Entretanto, para a indução da embriogênese somática em calos de citros, o fator mais importante é a resposta a alguns carboidratos no meio de cultivo. Kunitake et al. (1991), ao trabalhar com protoplastos de 3 variedades de tangerina 'Satsuma', observou o efeito de 5 carboidratos, sacarose, lactose, glicose, frutose e galactose, na embriogênese somática, obtendo resposta apenas no meio com lactose para as 3 variedades. Kochba et al. (1982), observaram que tanto a galactose e quanto a lactose influenciaram positivamente a embriogênese somática, sendo que a sacarose estimulou-a somente a níveis baixos (de 8 a $32 \mathrm{mM}$ ) e os carboidratos menos efetivos foram a glicose e a frutose. $O$ efeito destes carboidratos também foi reportada por 
Kobayashi et al. (1984) e Kunitake et al. (1991). Mendes-da-Glória (1998), trabalhando com calos embriogênicos oriundos de fusão de protoplastos, concluiu que a maltose foi o carboidrato mais efetivo e a sacarose, a que menos estimulou a embriogênese somática. Button (1978), Kochba et al. (1982) e BenHayyim \& Neumann (1983) relataram que a embriogênese somática de calos nucelares pôde ser estimulada quando a sacarose do meio foi substituída por alguns carboidratos, como a galactose, a lactose e o glicerol. Kochba et al. (1978) propuseram que este fenômeno pode ser devido à redução da auxina endógena nos calos embriogênicos. Kochba et al. (1982) ainda concluem que a eficiência dos carboidratos em estimular a embriogênese somática está relacionada ao genótipo.

\subsubsection{Confirmação da hibridação somática}

Espera-se que os híbridos somáticos tenham uma morfologia vegetativa intermediária entre os progenitores, sejam tetraplóides e manifestem uma expressão composta de marcadores moleculares. As técnicas disponiveis para a averiguação da hibridação somática é a análise da morfologia dos órgãos, especialmente das folhas, a determinação do número de cromossomos durante a mitose e a caracterização molecular mediante marcadores como isoenzimas e RAPD, podendo-se, ainda, realizar a comparação da eletroforese de proteínas totais ou cromatografia com óleos essenciais das folhas (Grosser \& Gmitter Junior, 1990a). O número de cromossomos é visualizado em preparações citológicas de pontas de raiz, em que se paraliza a mitose na metáfase, possibilitando a sua contagem (Grosser \& Gmitter Junior, 1990a; Vieira, 1988).

Outros métodos de confirmação da hibridação são apontados, como o estudo das subunidades polipeptídicas da RUBISCO, o padrão de restrição do DNA mitocondrial (mtDNA) e do DNA do cloroplasto (cpDNA) (Morikawa \& 
Yamada, 1992). Entretanto, estes métodos mais sofisticados ainda não estão muito difundidos nos trabalhos de hibridação de citros.

\subsection{Considerações finais}

A biotecnologia vem contribuir para o melhoramento genético vegetal, especialmente daquelas plantas que apresentam dificuldade de serem melhoradas pelos métodos convencionais, entre as quais estão os citros.

Uma vez que urge a necessidade de ampliar-se a base genética da citricultura brasileira, e também mundial, dado o pequeno número de variedades de copa e porta-enxerto bem aceitas pelos produtores, a hibridação somática, através da fusão de protoplastos, vem trazer novas expectativas ao melhoramento genético destas espécies.

Esta revisão mostra claramente que os protocolos desde a obtenção dos protoplastos até a sua regeneração em plantas já estão bem estabelecidos, entretanto, faz-se necessária a adaptação de cada etapa do processo aos diversos genótipos que devem ser estudados.

Os experimentos contidos neste trabalho tiveram o principal objetivo de contribuir para a adequação dos protocolos às diversas variedades estudadas, visando a obtenção de novas variedades que sejam interessantes à citricultura nacional. O primeiro capítulo refere-se à obtenção de calos embriogênicos, que são fontes de protoplastos, a maximização do processo de regeneração via embriogênese somática e do isolamento dos protoplastos. No segundo capítulo objetivou-se a obtenção de uma variedade tetraplóide que possa ser utilizada como porta-enxerto pelos citricultores, sendo alternativa ao porta-enxerto mais cultivado no Brasil, o limão 'Cravo'. 


\section{CALOGÊNESE, EMBRIOGÊNESE SOMÁTICA E ISOLAMENTO DE PROTOPLASTOS EM VARIEDADES DE LARANJA DOCE (Citress sinensis \\ L. Osbeck)}

\subsection{Resumo}

Com o objetivo de produzir calos embriogênicos de citros, óvulos abortados de frutos maduros de 6 variedades de laranja doce (Citrus sinensis $\mathrm{L}$. Osbeck), 'Bahia Cabula', 'Baianinha', 'Hamlin', 'Orvalho de Mel', 'Rubi' e 'Valência', foram introduzidos em meio de cultivo MT modificado com adição de extrato de malte, com è sem adição $5 \mathrm{mg} \cdot \mathrm{L}^{-1}$ benziladenina (BA). Os calos obtidos das variedades 'Bahia Cabula', 'Orvalho de Mel', 'Rubi' e 'Valência' foram cultivados em meio basal MT (Murashige \& Tucker), contendo os carboidratos maltose, galactose, lactose, glicose ou sacarose nas concentrações de 18; 37; 75; 110 e 150 mM para a indução da embriogênese somática. Os calos destas mesmas variedades foram submetidos ao isolamento de protoplastos, com o uso de 3 soluções enzimáticas. Os resultados revelaram que há influência do genótipo sobre a calogênese. A embriogênese somática foi estimulada na presença de galactose, para a maioria das variedades. A solução enzimática composta de $1 \%$ celulase, $1 \%$ macerase e $0,2 \%$ pectoliase foi a mais adequada para $\mathrm{o}$ isolamento de protoplastos a partir de calos das variedades de laranja doce estudas. 


\subsection{Summary: CALLUS INDUCTION, SOMATIC EMBRYOGENESIS AND PROTOPLAST ISOLATION FROM SWEET ORANGE (Citrus simensis L. Osbeck)}

Intending to produce embryogenic citrus calli (Citrus sinensis L. Osbeck), aborted ovules of ripe fruits from six sweet orange varieties, namely 'Bahia Cabula', 'Baianinha', 'Hamlin', 'Orvalho de Mel', 'Rubi' and 'Valencia', were introduced to modifyed MT medium, with and without benzyladenine (BA). Calli obtained from 'Bahia Cabula', 'Orvalho de Mel', 'Rubi' and 'Valencia' varieties were submitted to somatic embryogenic induction and carbohydrates and its concentrations studied were maltose, galactose, lactose, glucose and sucrose at $18 ; 37 ; 75 ; 110$ and $150 \mathrm{mM}$. Calli from same genotypes were submitted to protoplast isolation, using three enzymatic solutions. Results reveled the genotype effect in the callus induction. Somatic embryogenesis was stimulated in presence of galactose, for most varieties. Enzymatic solution composed by $1 \%$ cellulase, $1 \%$ macerase and $0,2 \%$ pectolyase was the best for callus isolation from all genotypes tested.

\subsection{Introdução}

O Brasil é hoje o principal produtor de frutas cítricas do mundo, perfazendo $23,7 \%$ da produção mundial, com mais de 24 milhões de toneladas de citros. Cerca de $95 \%$ da produção brasileira de citros está baseada em variedades de laranja doce, especialmente para o processamento industrial (FAO, 1999; Nonino, 1995; FNP Consultoria \& Comércio, 1999).

Apesar da hegemonia brasileira na produçăo cítrica mundial, há vários fatores que impedem um aumento na produtividade da cultura, como a susceptibllidade das variedades utilizadas a diversas doenças, pragas $\theta$ 
anormalidades fisiológicas, como o cancro cítrico, a clorose variegada dos citros, o declínio dos citros, a pinta-preta, a leprose e, ainda, a baixa adaptação às condições edafoclimáticas (Fundecitrus, 1999; Domingues, 1997).

O melhoramento genético é imprescindível para a transposição destas adversidades e deve ser utilizado para a manutenção da liderança brasileira na produção mundial. Entretanto, o melhoramento convencional têm sido limitado devido a fatores inerentes à biologia dos citros, como alta heterozigose, longo período juvenil, esterilidade do grão de pólen, incompatibilidade sexual e poliembrionia nucelar (Grosser \& Gmitter Junior, 1990b; Ling et al., 1989; Soost \& Cameron, 1975; Vardi \& Galun, 1989). A fusão de protoplastos constitui-se em uma nova e viável alternativa no melhoramento de citros, produzindo híbridos somáticos potencialmente capazes de gerar variedades superiores, especialmente por produzir plantas tetraplóides, sem segregação genética (Gmitter Junior et al., 1992).

A calogênese das espécies cítricas em cultivo in vitro pode ocorrer a partir de diversos tecidos, como óvulos (abortados, não fertilizados, inteiros fertilizados) e nucelos, sendo esta a fonte mais utilizada (Gmitter Junior \& Moore, 1986; Sim et al., 1988, Starrantino \& Russo, 1980). O meio de cultivo mais freqüentemente utilizado é o MT suplementado com $500 \mathrm{mg} \cdot \mathrm{L}^{-1}$ de extrato de malte (Lorenzo et al., 1994). A adição de reguladores de crescimento, como benziladenina (BA), cinetina, ácido indolilacético (IAA) e ácido 2,4diclorofenoxiacético (2,4-D), podem beneficiar o processo (Cristofani, 1991; Vardi et al., 1982; Oliveira, 1993).

A embriogênese somática a partir de calos também é um processo crítico na regeneraçăo de plantas e deve ser otimizada para cada variedade em estudo, especialmente em relaçăo à fonte de carbono adicionada ao meio de cultivo (Kochba et al., 1982). O carboidrato mais utilizado em meios de cultivo, para o crescimento de calos e cólulas em suspensão de cltros, é a sacarose 
(145 mM) (Jumin \& Nito, 1996a, 1996b), não sendo esta, necessariamente, a melhor condição para a expressão da embriogênese somática.

A hibridação somática de citros utiliza protoplastos isolados de suspensões celulares, de calos embriogênicos ou do mesofilo. Assim, o isolamento de protoplastos a partir de calos deve ser estudado e maximizado para cada espécie e variedade (Kunitake \& Mii, 1995).

Este trabalho teve por objetivo o estudo dos procedimentos básicos para a adequação das técnicas de fusão de protoplastos, incluindo a produção de calos a partir de óvulos abortados de variedades de laranja doce, o estudo da embriogênese somática e o isolamento dos protoplastos a partir destes calos.

\subsection{Material e Métodos}

Os experimentos foram realizados no Laboratório de Biotecnologia de Plantas Hortícolas, do Departamento de Produção Vegetal (ESALQ/USP), e no Laboratório de Biotecnologia Vegetal, (CENA/USP), em Piracicaba-SP.

\subsubsection{Calogênese}

Foram coletados frutos maduros de 6 variedades de laranja doce (Citrus sinensis L. Osbeck) do Banco de Matrizes do Centro de Citricultura "Sylvio Moreira” (IAC), em Cordeirópolis (SP): 'Bahia Cabula', 'Baianinha', 'Hamlin', 'Orvalho de Mel', 'Rubi' $\Theta$ 'Valência'. Óvulos abortados foram extraídos dos frutos, colocados em solução de hipoclorito de sódio a 1\%, por 20 minutos. Após a assepsia, o material foi lavado com água desmineralizada $\theta$ autoclavada. O meio de cultura basal utilizado foi o meio de cultura MT, modificado com $500 \mathrm{mg} \cdot \mathrm{L}^{-1}$ de extrato de malte, com ou sem a adiçăo de BA (5 mg. $\left.\mathrm{L}^{-1}\right)$. Foram inoculados 20 óvulos por placa de Petri $(100 \times 15 \mathrm{~mm})$ e 0 
material foi incubado à temperatura de $27^{\circ} \mathrm{C}$, em ausência de luz por um período de 28 semanas, subcultivado para meio de cultura fresco em intervalos de 4 semanas. $O$ delineamento experimental utilizado foi inteiramente casualizado no esquema fatorial 6 variedades $\times 2$ meios de cultivo. 0 número de óvulos implantados variou entre os tratamentos em função da disponibilidade do material e contaminações posteriores, a saber, nos meios sem e com BA: 'Bahia Cabula', 100 e 120; 'Baianinha', 140 e 100; 'Hamlin', 120 e 160; 'Orvalho de Mel', 80 e 60; 'Rubi', 60 e 40 e 'Valência', 20 e 40 óvulos abortados. As avaliações foram realizadas após 4,8 e 16 semanas de incubação, determinando-se o número de óvulos abortados que originaram calos friáveis. $A$ manutenção destes calos foi realizada por subcultivos mensais, em meio de cultivo MT modificado, sem adição de reguladores.

\subsubsection{Embriogênese somática}

Os calos das variedades 'Bahia Cabula', 'Orvalho de Mel', 'Rubi' e 'Valência' foram incubados em meio de cultura MT modificado com 500 mg.L-1 de extrato de malte contendo maltose, galactose, lactose, glicose e sacarose, nas concentrações de $18 ; 37 ; 75 ; 110$ e $150 \mathrm{mM}$, à temperatura de $27^{\circ} \mathrm{C}$, sob luz difusa (2500 lux). O delineamento experimental utilizado foi inteiramente ao acaso, com 4 repetições, sendo cada repetição constituída de uma placa de Petri $(100 \times 15 \mathrm{~mm})$, com $50 \mathrm{mg}$ de calo. A avaliação foi realizada após 4 semanas, determinando-se o número de embriões somáticos desenvolvidos, com o auxílio de microscópio esterioscópico $(7,5 \mathrm{x})$. Cada variedade foi analisada independentemente. 


\subsubsection{Isolamento de protoplastos}

Para a obtenção dos protoplastos das mesmas variedades usadas no experimento de embriogênese foram utilizadas 3 soluções enzimáticas: 1) $1 \%$ celulase Onozuka RS (Yakult Honsha), 1\% macerase R-10 (Yakult Honsha) e 0,2\% pectoliase $\mathrm{Y}-23$ (Seishin); dissolvidas em solução de 0,7 M manitol, 24,5 $\mathrm{mM} \mathrm{CaCl} 2.2 \mathrm{H}_{2} \mathrm{O}, 0,92 \mathrm{mM} \mathrm{NaH} \mathrm{PO}_{4}$ e 6,15 mM ácido 2-[N-morfolino]etanossulfônico (MES); pH 5,6 (Grosser \& Gmitter Junior, 1990a), utilizando-se $2 \mathrm{~mL}$ desta solução por placa de isolamento, diluído em $2 \mathrm{~mL}$ de meio $\mathrm{BH}_{3} 0,7 \mathrm{M}$ (Mourão Filho, 1995); 2) 0,2\% celulase Onozuka R-10, 0,3\% macerase R-10 e $0,1 \%$ driselase (Kyowa Hakko Kogyo), dissolvidas em solução com metade dos macroelementos do meio de cultura MT e 0,7 M manitol, pH 5,7, utilizando $5 \mathrm{~mL}$ desta solução por placa de isolamento (Kobayashi et al., 1983); 3) 1\% celulase Onozuka R-10, 0,2\% macerase R-10 e 0,1\% driselase (d'Útra-Vaz et al., 1993), dissolvidas em CPW 13M (Frearson et al., 1973) com 5 mM MES; pH 5,6, utilizando-se $10 \mathrm{~mL}$ da solução em cada placa de isolamento. Aproximadamente $500 \mathrm{mg}$ de calo foram colocados em cada placa de isolamento $(60 \times 15 \mathrm{~mm})$, juntamente com a solução enzimática, incubando-se por 16 horas, sob agitação orbital de 40 rpm, em ausência de luz, à temperatura de $27^{\circ} \mathrm{C}$. Para purificação utilizou-se peneira de nylon (malha de $50 \mu \mathrm{m}$ ) e centrifugações a 700 rpm, por 5 minutos. A avaliação foi realizada com auxílio de câmara de Neubauer, determinando-se o número de protoplastos por mililitro. $O$ delineamento experimental utilizado foi o inteiramente ao acaso, com 3 repetições, sendo cada repetição constituída por uma placa de isolamento. 


\subsection{Resultados e Discussão}

A calogênese dos óvulos abortados não ocorreu até 8 semanas de cultivo. A Tabela 1 apresenta os dados da porcentagem de óvulos abortados que resultaram em calos friáveis após 16 semanas de incubação.

Tabela 1. Calogênese a partir de óvulos abortados de variedades de Iaranja doce

\begin{tabular}{ccc}
\hline & Quantidade de óvulos responsivos \\
\hline variedade & meio MT & meio MT+BA \\
'Hamlin' & $3,3 \%$ & $1,3 \%$ \\
'Baianinha' & $1,4 \%$ & 0,0 \\
'Rubi' & $15,0 \%$ & $12,5 \%$ \\
'Bahia Cabula' & $2,0 \%$ & $0,8 \%$ \\
'Valência' & 0,0 & $2,5 \%$ \\
'Orvalho de Mel' & $3,8 \%$ & 0,0 \\
\hline
\end{tabular}

Observa-se superioridade da variedade 'Rubi', que apresentou calogênese em $12,5 \%$ e $15 \%$ dos óvulos introduzidos, nos meios de cultura com e sem BA, respectivamente, enquanto em outras variedades não foi conseguido induzir a calogênese em ambos os meios utilizados. As variedades 'Baianinha' e a 'Orvalho de Mel' não apresentaram formação de calos em meio com BA e a 'Valência' não apresentou formação de calos em meio de cultivo sem $B A$.

Outros autores também constataram o efeito do genótipo sobre a resposta à indução da calogênese. Mendes-da-Glória (1998), trabalhando com diversas variedades de citros, não obteve formação de calos nas variedades 'Natal' e 'Pêra', enquanto as variedades 'Serra d'água' e 'Valência' foram menos 
responsivas em relação às variedades de tangerinas 'Cravo' e 'Ponkan' e tangor 'Murcote' estudadas no experimento, que chegaram a mais de $40 \%$ de resposta. Oliveira et al. (1994) também observou o efeito do genótipo na calogênese com tangerina 'Cleópatra', limão 'Cravo' e Poncirus trifoliata, obtendo $48,8 \%$ de resposta para a primeira variedade, sem conseguir sucesso, no entanto, com trifoliata. Mourão Filho \& Grosser (1992), ao trabalhar com 30 seleções de citros, incluindo espécies relacionadas, constataram que a resposta foi variável, desde genótipos que não produziram calos, como Clausena, até outros que produziram calos friáveis de rápida proliferação, como o limão 'Rugoso'. Outra constatação neste mesmo trabalho foi a influência do meio de indução sobre a calogênese. O limão 'Rugoso' apresentou calos friáveis em meio de cultura com 2,4-D e cinetina, enquanto em meio com cinetina e NAA apresentou calos duros. Oliveira et al. (1994) observaram que nucelos de tangerina 'Cleópatra' em meio com IAA e cinetina responderam em 78,8\%, enquanto a mesma variedade, em meio com BA resultou em $16,3 \%$ de resposta. Tangerinas 'Cleópatra' e 'Sunki' clone 'CNPMF 02' e laranja 'Hamlin' clone 20 apresentaram 34,6; 30,7 e 23,5\% de formação de calos embriogênicos, respectivamente, em meio MT com $500 \mathrm{mg} \cdot \mathrm{L}^{-1}$ de extrato de malte e $10 \mathrm{mg.L^{-1 }}$ de BA (Zanol et al., 1997). Entretanto, no mesmo trabalho, não obteve-se resultado na indução à calogênese com limão 'Cravo' clone 'Santa Bárbara', limão 'Volkameriano', limão 'Rugoso Mazoe', laranja 'Hamlin' clone 04, laranja 'Azeda', Poncirus trifoliata seleção 'Flying Dragon' e citranges 'Carrizo', 'Troyer' e 'C-35'.

Um eficiente sistema de regeneração de plantas a partir de cultura de tecidos e células é reconhecidamente um pré-requisito para a aplicação das técnicas de biotecnologia no melhoramento vegetal (Litz \& Gray, 1992). A embriogênese somática é reconhecida como o processo mais comum na regeneração das plantas cltricas. 
Vários autores observaram que a alteração do carboidrato no meio de cultivo gera uma resposta na indução da embriogênese somática em citros. Button (1978) observou que a sacarose promove bom crescimento de calos cítricos, entretanto, Kochba et al. (1982) relatou que este carboidrato não estimulou a embriogênese somática, enquanto a galactose e a lactose foram os que mais estimularam o processo. Mendes-da-Glória (1998), ao trabalhar com calos cítricos oriundos de fusão de protoplastos, concluiu que a maltose foi o melhor carboidrato para a indução da embriogênese somática, sendo este efeito mais intenso em algumas combinações que em outras. Ben-Hayyim \& Neumann (1983) e Vu et al. (1993) relatam que a embriogênese somática pode ser estimulada quando a sacarose é substituída por glicerol no meio de cultivo.

O presente experimento explorou o potencial embriogênico dos calos das variedades 'Bahia Cabula', 'Orvalho de Mel', 'Rubi' e 'Valência' em relação a diversos carboidratos (Tabela 2). Verifica-se diferenças na resposta à indução de formação de embriões entre as variedades de citros. Enquanto as variedades 'Bahia Cabula' e 'Rubi' chegaram a produzir 1887 e 2077 embriões por $50 \mathrm{mg}$ de calo, 'Valência' e 'Orvalho de Mel' apresentaram 738 e 621 embriões para a mesma massa de calo, respectivamente. A Figura 1 mostra embriões somáticos sendo originados a partir de calo embriogênico da variedade 'Rubi'. Ainda, os dados apontam para a galactose como responsável pelas melhores respostas, embora a sua melhor concentração seja diferente para cada variedade em estudo. Este carboidrato, nas suas doses mais baixas, foi o que apresentou os melhores resultados, com exceção da 'Valência', que teve seu pico a $150 \mathrm{mM}$. A glicose foi o segundo carboidrato que melhor estimulou a embriogênese somática, resultando no maior número de embriões, depois da galactose, para todas as variedades. Os bons resultados de estímulo à embriogênese obtidos com lactose e maltose por Kochba et al. (1982) e Mendes-da-Glória (1998), respectivamente, năo foram observados para as variedades estudadas, fortalecendo a afirmaçăo de que existem diferenças na 
resposta ao estímulo embriogênico aos diversos carboidratos entre as espécies e variedades de citros (Vardi et al., 1982).

Entre as hipóteses para explicar o efeito da galactose no estímulo à embriogênese somática e ao desenvolvimento ontogenético do embrião, temos que este carboidrato poderia inibir a biossíntese de auxina ou o seu transporte (Anker, 1974; Yamamoto et al., 1988; Krul \& Colclasure, 1977), inibindo, assim, a embriogênese somática em Citrus pela modificação do balanço endógeno da auxina. Reforçando esta hipótese, Epstein et al. (1977) observou que ocorre o acúmulo de auxinas conjugadas com aspartato em células embriogênicas de laranja doce, enquanto isto não acontece com as não embriogênicas. $A$ galactose estimulou a biossíntese de etileno em trabalhos feitos por Colclasure \& Yopp, (1976), especialmente em sinergismo com auxinas (Jongkee et al., 1987). A adição de ethephon em meios de cultura de calos de citros induziu a embriogênese somática (Kochba et al., 1978), indicando que o efeito da galactose pode ser o de estimular a biossíntese de etileno.

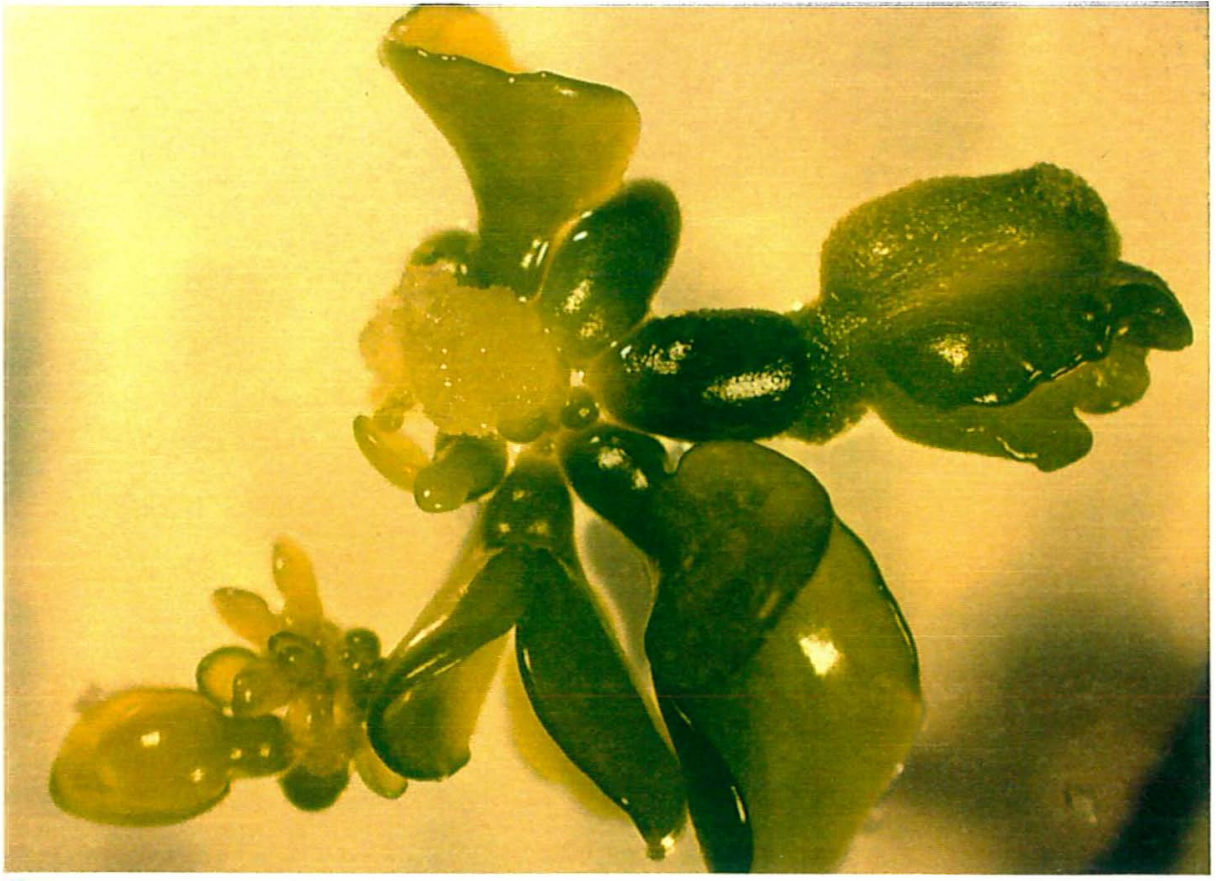

Figura 1. Embriões somáticos originando-se a partir de calo embriogênico de laranja 'Rubi' 
Tabela 2. Embriogênese somática de calos de variedades de laranja doce em resposta ao tipo e à concentração de carboidratos adicionados ao meio de cultivo, após 4 semanas de incubação.

\begin{tabular}{|c|c|c|c|c|c|}
\hline \multirow[b]{2}{*}{ Carboidratos } & \multirow[b]{2}{*}{$\mathbf{m M}$} & \multicolumn{4}{|c|}{ Variedades } \\
\hline & & 'Bahia Cabula' & 'Orvalho de Mel' & 'Rubi' & 'Valência' \\
\hline \multirow{5}{*}{ sacarose } & 18 & $1078 \pm 198$ & $357 \pm 109$ & $1160 \pm 171$ & $261 \pm 80$ \\
\hline & 37 & $546 \pm 80$ & $319 \pm 69$ & $1605 \pm 135$ & $313 \pm 51$ \\
\hline & 75 & $683 \pm 95$ & $467 \pm 26$ & $657 \pm 48$ & $187 \pm 93$ \\
\hline & 110 & $347 \pm 69$ & $421 \pm 122$ & $841 \pm 131$ & $392 \pm 36$ \\
\hline & 150 & $559 \pm 66$ & $257 \pm 31$ & $719 \pm 145$ & $523 \pm 163$ \\
\hline \multirow{5}{*}{ galactose } & 18 & $1887 \pm 294$ & $621 \pm 104$ & $899 \pm 235$ & $558 \pm 279$ \\
\hline & 37 & $1840 \pm 179$ & $202 \pm 31$ & $2077 \pm 311$ & $504 \pm 101$ \\
\hline & 75 & $987 \pm 302$ & $478 \pm 129$ & $1270 \pm 74$ & $201 \pm 135$ \\
\hline & 110 & $937 \pm 197$ & $437 \pm 140$ & $704 \pm 207$ & $501 \pm 126$ \\
\hline & 150 & $958 \pm 232$ & $343 \pm 67$ & $657 \pm 161$ & $738 \pm 273$ \\
\hline \multirow{5}{*}{ maltose } & 18 & $542 \pm 123$ & $169 \pm 76$ & $682 \pm 133$ & $119 \pm 82$ \\
\hline & 37 & $221 \pm 101$ & $17 \pm 7$ & $668 \pm 213$ & $254 \pm 80$ \\
\hline & 75 & $154 \pm 59$ & $70 \pm 38$ & $801 \pm 136$ & $140 \pm 76$ \\
\hline & 110 & $103 \pm 20$ & $36 \pm 24$ & $737 \pm 211$ & $69 \pm 22$ \\
\hline & 150 & $82 \pm 9$ & $70 \pm 42$ & $864 \pm 178$ & $311 \pm 188$ \\
\hline \multirow{5}{*}{ lactose } & 18 & $381 \pm 196$ & $29 \pm 16$ & $498 \pm 22$ & $455 \pm 268$ \\
\hline & 37 & $379 \pm 154$ & $85 \pm 31$ & $845 \pm 295$ & $27 \pm 12$ \\
\hline & 75 & $500 \pm 161$ & $532 \pm 360$ & $912 \pm 320$ & $127 \pm 74$ \\
\hline & 110 & $299 \pm 89$ & $396 \pm 273$ & $942 \pm 130$ & $307 \pm 148$ \\
\hline & 150 & $218 \pm 181$ & $98 \pm 77$ & $951 \pm 277$ & $118 \pm 118$ \\
\hline \multirow{5}{*}{ glicose } & 18 & $1111 \pm 144$ & $356 \pm 124$ & $1140 \pm 301$ & $348 \pm 135$ \\
\hline & 37 & $868 \pm 201$ & $310 \pm 79$ & $1727 \pm 268$ & $425 \pm 93$ \\
\hline & 75 & $1011 \pm 84$ & $292 \pm 72$ & $945 \pm 221$ & $242 \pm 80$ \\
\hline & 110 & $662 \pm 157$ & $575 \pm 92$ & $400 \pm 76$ & $621 \pm 133$ \\
\hline & 150 & $975 \pm 169$ & $205 \pm 92$ & $551 \pm 171$ & $595 \pm 199$ \\
\hline
\end{tabular}


Uma terceira hipótese para o efeito da galactose na embriogênese somática coloca este carboidrato como inibidor da síntese de UDP-glicose, um intermediário da síntese da fração não celulósica das paredes celulares (Masuda, 1990) ou da conversão da UDP-glicose a glicose-1-fosfato, pelo acúmulo de galactose-1-fosfato (Kochba et al., 1982). Em cana-de-açúcar, culturas em suspensão com galactose continham 35\% mais galactose-quinase que as células em meio com sacarose, tendo, ainda, dez vezes mais UDPgalactose-4-epimerase, uma enzima-chave para a entrada da galactose na glicólise (Maretzki \& Thom, 1978).

Outro passo importante nos procedimentos biotecnológicos de melhoramento de citros é a obtenção de protoplastos viáveis. Os calos de citros são, muitas vezes, recalcitrantes à digestão da parede celular, dificultando, o isolamento de protoplastos. Diversos fatores estão envolvidos neste processo, como o tipo e concentração das enzimas digestivas utilizadas, o potencial osmótico da solução de isolamento e a estrutura física da parede das células do calo em estudo. A maximização do isolamento é uma etapa fundamental na adequação das técnicas que utilizam o protoplasto como base, tal qual a hibridação somática.

Vardi \& Galun (1988; 1989), relatam que as espécies de citros e as variedades de uma mesma espécie, mostram uma grande variação na eficiência de isolamento perante as diversas soluções enzimáticas empregadas, concluindo que uma combinação enzimática apropriada deve ser determinada para cada calo especificamente. As soluções enzimáticas relatadas para citros permitem classifícá-las em dois grupos com relação ao tempo de digestão enzimática: soluções fortes, em que o isolamento de protoplastos ocorre em 4 horas (Goldman, 1988) e soluções fracas, nas quais o isolamento se dá em cerca de 16 horas (Vardi et al., 1982).

Os resultados do experimento realizado, constrastando três soluções enzimáticas, estão representados na Figura 2. Observa-se claramente que a 
solução enzimática composta por $1 \%$ celulase, $1 \%$ macerase e $0,2 \%$ macerase (Grosser \& Gmitter Junior, 1990a) foi a melhor para todas as variedades estudadas, nas condições realizadas. As variedades que apresentaram maior rendimento no isolamento, na solução descrita por Grosser \& Gmitter Junior (1990a) foram a 'Valência' e a 'Rubi', com 66,25 × 104 e 52,63 $\times 10^{4}$ protoplastos isolados a partir de $500 \mathrm{mg}$ de calo, enquanto a 'Orvalho de Mel' e a 'Bahia Cabula' tiveram rendimento de $23,63 \times 10^{4}$ e 7,88 x 104 protoplastos. Oliveira et al. (1995), ao isolar protoplastos de tangerina 'Cleópatra', obtiveram rendimento de 4,7 × 106 protoplastos por grama de calo, enquanto Cristofani (1991) e Goldman (1988), ao trabalhando com laranja 'Pêra', conseguiram médias de $1,43 \times 10^{6}$ e $1,37 \times 10^{6}$ por grama de calo, respectivamente. Constrantando-se estes resultados ao conseguido no presente experimento, pode-se afirmar que, além da solução enzimática, outros fatores devem ser estudados para a maximização do isolamento das variedades estudadas, tais quais o subcultivo de calos em meio de cultura com menor quantidade de carboidrato e pré-tratamento enzimático, ambos propostos por Oliveira et al. (1995). 


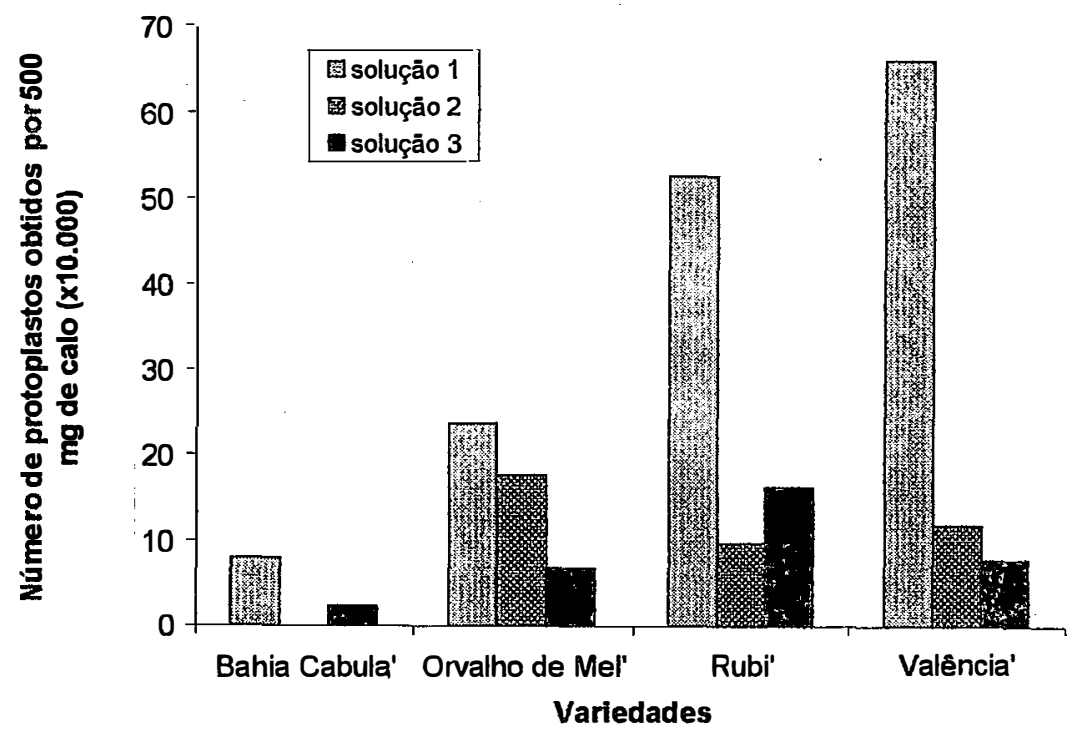

Figura 2. Eficiência de isolamento de protoplastos de calos embriogênicos de citros

\subsection{Conclusões}

Os resultados obtidos neste trabalho permitem afirmar:

1) A calogênese é altamente influenciada pelo genótipo em laranja doťe;

2) A embriogênese somática, para a maioria das variedades, teve a tendência de ser mais responsiva à indução pela galactose;

3) A solução enzimática composta por $1 \%$ celulase, $1 \%$ macerase e $0,2 \%$ pectoliase é a mais adequada para todas as variedades estudadas, mostrando-se a mais apropriada para 0 isolamento das variedades de laranja doce. 


\section{HIBRIDAÇÃO SOMÁTICA ENTRE TANGERINA 'CLEÓPATRA' (Citrus reshni Hort. Ex Tanaka) E LARANJA 'AZEDA' (Citrus aurantium L.) POR FUSÃO DE PROTOPLASTOS}

\subsection{Resumo}

Os protoplastos de tangerina 'Cleópatra' foram isolados a partir de calos embriogênicos e os protoplastos de laranja 'Azeda', do mesofilo de plântulas oriundas de cultivo in vitro. A hibridação somática foi realizada com polietilenoglicol ( $P M=1450)$. O plaqueamento e cultivo dos protoplastos deu-se em meio de cultura líquido. Embriōes somáticos originaram-se neste mesmo meio de cultura, já aos 60 dias de incubação. Após 250 dias da fusão os regenerantes foram aclimatados. A confirmação da hibridação somática deu-se por meio de marcadores moleculares tipo RAPD, utilizando-se 5 'primers' que mostraram diversas bandas polimórficas presentes no híbrido. A escolha dos parentais foi feita com vistas na complementariedade das características de ambos porta-enxertos, almiejando-se um porta-enxerto tolerante ao declínio, ao vírus da tristeza, resistente ao frio e à seca, boa produtividade e boa qualidade de frutos, além de induzir um menor porte na planta, dado o aumento no nível de ploidia. Desta forma, o híbrido somático tangerina 'Cleópatra' + laranja 'Azeda' apresenta potencial para a diversificação dos porta-enxertos dos pomares cítricos. 


\subsection{Summary: Somatic hybridization of 'Cleopatra' mandarin (Citrus reshni Hort. ex Tanaka) and Sour orange (Citrus auramtiem L.) via protoplast fusion}

'Cleopatra' mandarin protoplasts were isolated from embryogenic callus cells and sour orange protoplasts were isolated from the mesophyl of in vitro seedlings. Somatic hybridization was made using polyetilenoglycol ( $\mathrm{MW}=$ 1450). Protoplast plating and culture was performed in liquid medium. Somatic embryos appeared in this culture medium following 60 days of culture. Regenerants were acclimated 250 days after fusion. Somatic hybridization was evaluated by Randomly Amplified Polymorfic DNA (RAPD) molecular markers, with 5 primers which produced several polymorfic fragments that were present in the hybrid. Parental selection was made using complementary traits from both rootstocks. A rootstock with tolerance or resistence to citrus blight, tristeza virus, cold and drought, high quantity yield, high quality fruit and smaller tree size (due ploidy level). Therefore, the 'Cleopatra' mandarin + sour orange somatic hybrid has a potential for citrus rootstocks diversification.

\subsection{Introdução}

A citricultura brasileira participou mundialmente, em 1998, com mais de 23 milhões de toneladas de laranja, perfazendo $34,8 \%$ da produção mundial. Os Estados Unidos vieram em segundo lugar, com cerca de 16 milhões de toneladas (FAO, 1999). Com isto, fica evidente a importância social e econômica desta cultura para o Brasil.

Entretanto, a estrutura genética sobre a qual está baseada a citricultura brasileira apresenta grande fragilidade, devido especialmente à sua estreita 
base. Desta maneira, poucas são as variedades utilizadas amplamente pelos citricultores (Moreira \& Pio, 1991).

Entre as décadas de 30 e 40, o Brasil perdeu praticamente toda a cultura de citros, em decorrência da maioria dos pomares estarem enxertados sobre a laranja 'Azeda' (Citrus aurantium L.), susceptível à tristeza (Moreira \& Moreira, 1991). Atualmente mais de $90 \%$ da citricultura brasileira está enxertada sobre limão 'Cravo' (Citrus limonia L. Osbeck). Embora apresente muitas características favoráveis, há inconvenientes que preocupam os produtores, como a susceptibilidade ao declínio do citros e à gomose (Pompeu Junior, 1991).

Variedades alternativas ainda não se estabeleceram completamente por não apresentarem características que equivalham às do limão 'Cravo', como alta resistência à seca, grande vigor no viveiro, precocidade de início de produção e boa produtividade (Pompeu Junior, 1991).

Os programas convencionais de melhoramento de porta-enxertos cítricos através de cruzamentos sexuais enfrentam sérias restrições, como poliembrionia, esterilidade masculina e feminina, alta heterozigose e um longo período vegetativo (Soost \& Cameron, 1975).

O melhoramento via biotecnologia vem trazer alternativas na produção de variedades alternativas de porta-enxerto. Uma estratégia possível é a combinação de características complementares das variedades disponíveis sem a ocorrência da segregação gênica. Isto pode ser realizado através da hibridação somática via fusão de protoplastos. Espera-se que o híbrido assim produzido traga toda a carga genética de ambos os parentais, somando as características horticulturais desejáveis (Grosser \& Gmitter Junior, 1990a).

Este trabalho objetivou a produção de um híbrido somático entre a tangerina 'Cleópatra' (Citrus reshni Hort. ex Tanaka) e a laranja 'Azeda' (Citrus aurantium L.) , via fusão de protoplastos, esperando que a complementaçăo das caracterlsticas façam deste hibrldo uma alternativa ao uso do limåo 'Cravo'. 


\subsection{Material e Métodos}

\subsubsection{Material vegetal}

Calos embriogênicos de tangerina 'Cleópatra' (Citrus reshni Hort. ex Tanaka), obtidos do cultivo de tecidos nucelares e mantidos em meio MT suplementado com $500 \mathrm{mg} \cdot \mathrm{L}^{-1}$ de extrato de malte foram a fonte de extração dos protoplastos de uma das variedades parentais. Os protoplastos da outra variedade, laranja 'Azeda' (Citrus aurantium L.), foram obtidos a partir do mesofilo de folhas oriundas de plântulas cultivadas in vitro em meio de enraizamento (RMAN) (Grosser \& Gmitter Junior, 1990a).

Os experimentos foram realizados no Laboratório de Biotecnologia de Plantas Hortícolas do Departamento de Produção Vegetal da ESALQ/USP, em Piracicaba-SP. As etapas de confirmação da hibridação somática foram feitas no Laboratório de Biotecnologia Vegetal do Centro de Energia Nuclear na Agricultura (CENA/USP), também em Piracicaba-SP.

\subsubsection{Isolamento e purificaçåo dos protoplastos}

Foi escolhida a metodologia para o isolamento, fusão e cultura dos protoplastos proposta por Grosser \& Gmitter Junior (1990a). Para o isolamento de protoplastos de calos e de mesofilo foi preparada solução enzimática com 0,7 $\mathrm{M}$ manitol, $24,5 \mathrm{mM} \mathrm{CaCl} 2.2 \mathrm{H}_{2} \mathrm{O}, 0,92 \mathrm{mM} \mathrm{NaH}_{2} \mathrm{PO}_{4}, 6,15 \mathrm{mM}$ ácido 2-[Nmorfolino]-etanossulfônico (MES), 1\% celulase Onozuka RS (Yakult Honsha), $1 \%$ macerase R-10 (Yakult Honsha) e 0,2\% pectinase $\mathrm{Y}-23$ (Seishin). O pH da soluçåo foi ajustado a 5,6 ө a esterilizaçăo foi felta por filtragem em membrana 
de nitrocelulose com malha de 0,2 $\mu \mathrm{m}$. Para o isolamento, a solução enzimática foi diluída em $\mathrm{BH}_{3}$ a 0,7 M (1:1). A incubação das células deu-se por 16 horas no escuro, com agitação orbital a 40 rpm.

A seguir os protoplastos foram purificados, filtrando-se em peneira de nylon (malha de $50 \mu \mathrm{m}$ ) e sofreram centrifugação por 5 minutos a $100 \mathrm{~g}$, visando remover os restos celulares não digeridos. Os protoplastos foram, então, purificados em gradiente de sacarose-manitol: o centrifugado foi delicadamente ressuspenso em $5 \mathrm{~mL}$ de meio CPW contendo sacarose a $25 \%$. Dois mililitros de meio CPW com manitol a 13\% (Frearson et al., 1973) foram colocados na parte superior da solução ressuspensa anteriormente, para formar um gradiente de densidade. Os tubos foram centrifugados por 6 minutos a 100 g. Os protoplastos viáveis ficaram na interface entre as duas soluções, após a centrifugação. Estas células foram removidas e ressuspensas em meio $\mathrm{BH}_{3}$.

\subsubsection{Fusão e cultivo dos protoplastos e regeneração das plantas}

Iguais quantidades de protoplastos purificados de cada fonte parental foram colocadas no centro de uma placa de Petri, adicionando-se duas gotas de solução recém-preparada de polietilenoglicol (PEG) (PM=1450). Esta mistura foi incubada por 8 minutos. Adicionou-se, então, duas gotas de solução de eluição $A+B(9: 1, v / v)$. Nova incubação ocorreu por 12 minutos. Depois, foram acrescidas 12 gotas de meio $\mathrm{BH}_{3}$ fresco ao redor da gota já instaurada. Nova incubação ocorreu por 5 minutos e a solução de eluição e PEG foi cuidadosamente removida com uma pipeta de Pasteur e repostas 15 gotas de meio $\mathrm{BH}_{3}$. Foram aguardados 10 minutos, sendo, então, repetida esta etapa por mais 2 vezes, tomando-se o cuidado para não remover os protoplastos da placa.

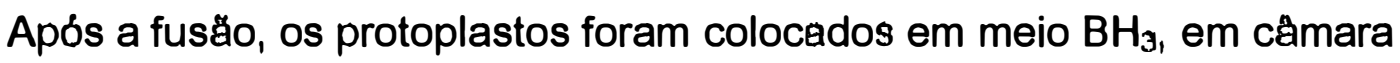
de crescimento a $27^{\circ} \mathrm{C}$, no escuro (Grosser \& Gmitter Jr., 1990a; Mourâo Filho, 
1995). Aos 30 dias de incubação fez-se um acréscimo de meios de protoplastos para redução osmótica $\left(\mathrm{BH}_{3}\right.$ a 0,6 M + EME a 0,6 M + EME a 0,15 $M$, em partes iguais) e a mudança para câmara de crescimento iluminada. Os embriões somáticos surgiram diretamente da placa de fusão com meio líquido, aos 60 dias. A germinação destes embriões ocorreu em meio EME com sacarose a $73 \mathrm{mM}$. O desenvolvimento destes embriões deu-se em meio idêntico, acrescido de $1 \mathrm{mg} \cdot \mathrm{L}^{-1}$ de ácido giberélico $\left(\mathrm{GA}_{3}\right)$. Após o desenvolvimento da parte áerea, as plântulas foram colocadas em meio de enraizamento (RMAN) (Grosser \& Gmitter Junior, 1990a). As plantas com sistema radicular bem desenvolvido foram transferidas para vasos com substrato comercial e solo, na proporção 3:1, cobertas com saco plástico por 30 dias, visando a sua adaptação às novas condições ambientais. Neste período o saco plástico foi sendo removido com freqüência crescente, de 2 a 5 vezes por dia, por 10 a 15 minutos, até a completa aclimatação das plantas.

\subsubsection{Confirmação da hibridação somática}

\subsubsection{Análise da morfologia foliar}

Grosser \& Gmitter Junior (1990a) afirmam que os híbridos interespecíficos de citros apresentam a asa do pecíolo de tamanho intermediário às dos parentais e que o aumento do nível da ploidia pode resultar no aumento da espessura da folha e uma coloração mais intensa do limbo foliar. Estas características foram analisadas preliminarmente nos regenerantes obtidos, apresentando as características descritas. 


\subsubsection{Análise molecular via RAPD}

A confirmação das fusões alotetraplóidicas foi realizada com o auxílio de marcadores moleculares de DNA, utilizando-se 'primers' aleatórios (RAPD) (Mourão Filho, 1995; Mendes-da-Glória, 1998; Latado, 1998).

\subsection{Extração de DNA}

Seguindo-se a metodologia de Hoisington et al. (1994), a extração do DNA foi feita por meio da moagem de 1-2 folhas das plântulas em nitrogênio líquido. O macerado foi colocado em tubos de 1,5 mL (Eppendorf) com $500 \mu \mathrm{L}$ de solução extratora [100 mM Tris- $\mathrm{HCl}$ pH=7,5, 50 mM Na 2 EDTA pH=8,0, 700 $\mathrm{mM} \mathrm{NaCl}, 140 \mathrm{mM} \beta$-mercaptoetanol e 1\% brometo de cetiltrimetilamônio (CTAB)]. Estas amostras foram, então, incubadas em banho-maria a $65^{\circ} \mathrm{C}$ por 10 minutos. Acrescentou-se $500 \mu \mathrm{L}$ de clorofórmio-álcool isoamílio '(24:1) e, após 5 minutos, centrifugou-se a $13000 \mathrm{rpm}$ por 10 minutos. $\mathrm{O}$ sobrenadante foi transferido para novos tubos e adicionado $400 \mu \mathrm{L}$ de solução saturada de fenol. Os tubos foram agitados com cuidado e novamente centrifugados a $13000 \mathrm{rpm}$ por 10 minutos. A fase aquosa foi transferida para novos tubos, adicionando-se, então, $400 \mu \mathrm{L}$ de etanol absoluto e mantendo-se em freezer $\left(-20^{\circ} \mathrm{C}\right)$ por 10 minutos. Os tubos foram centrifugados por 2 minutos; o sobrenadante, removido e o centrifugado, lavado em etanol $70 \%$. Os 'pellets' foram desidratados e finalmente dissolvidos em $100 \mu \mathrm{L}$ de TE $(10 \mathrm{mM}$ Tris- $\mathrm{HCl}$ e 1 $\mathrm{mM}$ EDTA, $\mathrm{pH}=8,0)$. Foi procedida uma reprecipitação do DNA com $1000 \mu \mathrm{L}$ de etanol absoluto e $130 \mu \mathrm{L}$ de $5 \mathrm{M} \mathrm{NaCl}$. Nova centrifugação por 10 minutos a $13000 \mathrm{rpm}$ foi realizada, o sobrenadante, descartado e o DNA precipitado foi submetido a uma solução de lavagem (etanol a 76\% e $1 \mathrm{M}$ acetato de potássio a $20 \%$ ) por 10 minutos. A soluçăo foi retirada e uma outra soluçåo de lavagem 
foi colocada no tubo (etanol a 76\% e $1 \mathrm{M}$ acetato de potássio a 10\%). Em seguida, a solução foi drenada e o DNA foi ressuspenso em $50 \mu \mathrm{L}$ de TE. A concentração final de DNA foi determinada em gel de agarose a $0,8 \%$ com padrões de DNA de lambda.

\subsection{Reação de amplificação do DNA}

Cada amostra continha no tubo de reação: $2,0 \mu \mathrm{L}$ de solução tampão 10X (200 mM Tris-HCl, pH=8,4 e 500 mM KCl) (Gibco), 2,5 mM de $\mathrm{MgCl}_{2}, 100$ $\mu \mathrm{M}$ cada dNTP, 250 nM 'primer', 30ng de DNA, 1 unidade de Taq-polimerase (Gibco). À reação foi acrescentada água Mili-Q esterilizada até o volume total de $20 \mu \mathrm{L}$. Óleo mineral foi adicionado ao tubo para evitar evaporação durante a reação. A programação utilizada foi a maximizada por Mendes-da-Glória (1998), cujas etapas foram: 1) $93^{\circ} \mathrm{C}$ por $2 \mathrm{~min}$; 2) $92^{\circ} \mathrm{C}$ por $1 \mathrm{~min}$; 3) $37^{\circ} \mathrm{C}$ por $1 \mathrm{~min}$; 4) $72^{\circ} \mathrm{C}$ por $\left.2 \mathrm{~min} ; 5\right) 72^{\circ} \mathrm{C}$ por $\left.5 \min ; 6\right) 4^{\circ} \mathrm{C}$ (fim). As etapas 2 a 4 foram repetidas 43 vezes.

Foram utilizados "primers" da Tecnologia Operon, série A (OPAA), tendose realizado o escrutínio do polimorfismo entre a tangerina 'Cleópatra' e a laranja 'Azeda' com os 20 "primers" da série A.

\subsection{Eletroforese e análise}

A seguir foi feita eletroforese em gel de agarose a $1,5 \%$ em solução tampão TBE (45 mM Tris-HCl, 45 mM ácido bórico e 1 mM EDTA, pH=8,0) com $5 \mu \mathrm{g}$ brometo de etídio por mililitro de gel. $\mathrm{O}$ gel foi submetido a corrente elétrica constante de 50 volts, em solução tampão TBE por 5-6 horas, à temperatura ambiente. $\mathrm{O}$ padrão de bandas foi examinado sobre luz ultravioleta. 


\subsection{Resultados e Discussão}

Isolamentos bastante eficientes foram alcançados a partir dos calos de tangerina 'Cleópatra' e do mesofilo de laranja 'Azeda'. A fusão ocorreu em número elevado (Figura 3) e a indução à embriogênese somática deu-se já diretamente na placa de fusão, quando do acréscimo de meio líquido, aos 60 dias de incubação. Os embriões desenvolveram-se muito rapidamente e aos 150 dias após a fusão já estavam com o sistema radicular formado. Aos 250 dias, os regenerantes foram aclimatados (Figura 4), tendo-se perdido menos de $10 \%$ das plantas, obtendo-se, assim, grande sucesso, uma vez que esta fase é tida como crítica. Grosser et al. (1992b), em experimentos de fusão de protoplastos também verificaram uma grande proliferação dos híbridos somáticos oriundos de fusões com tangerina 'Cleópatra', contribuindo para a regeneração de um grande número de plantas. 


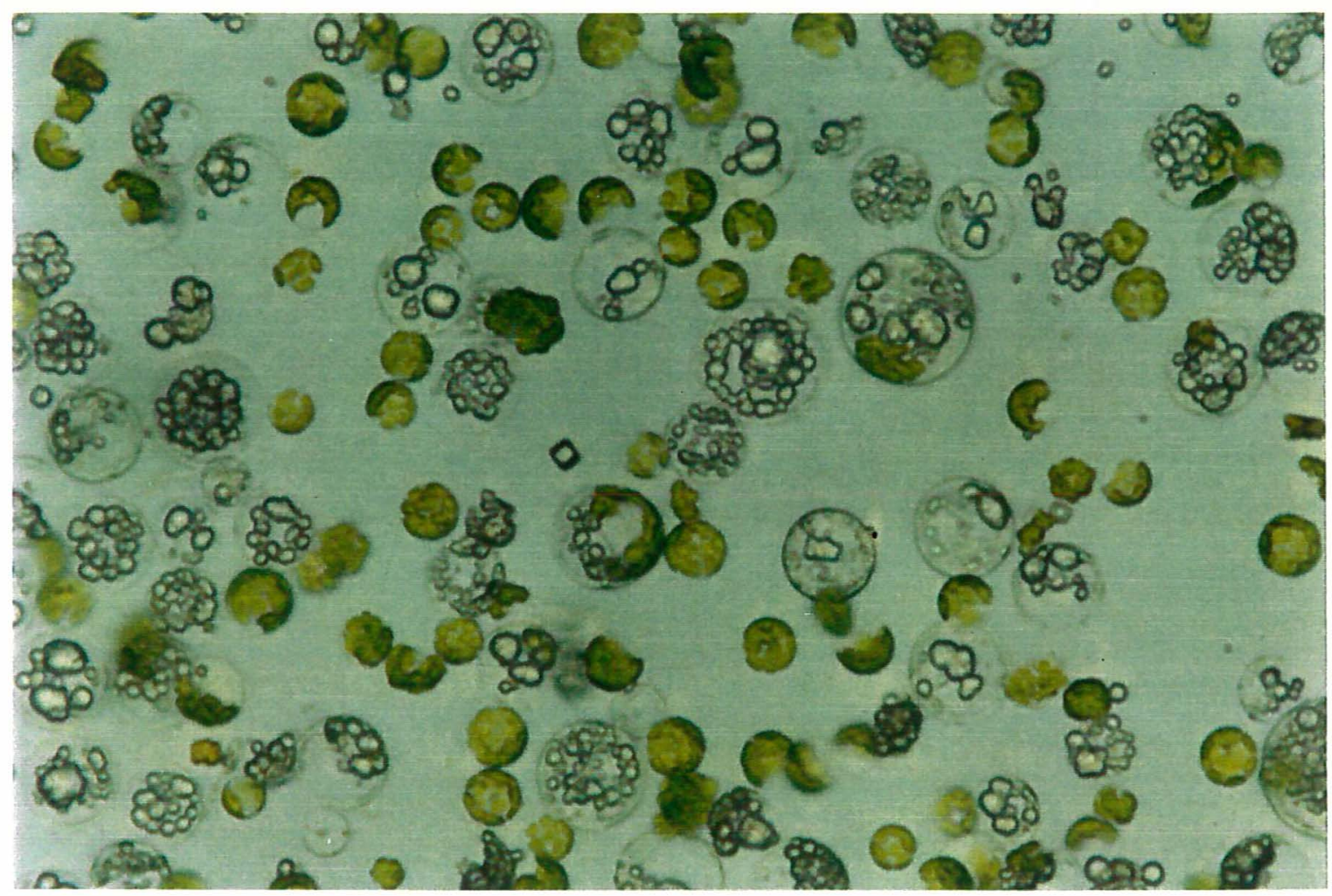

Figura 3. Fusão de protoplastos a partir de mesofilo de laranja 'Azeda' e calo embriogênico de tangerina 'Cleópatra'. 


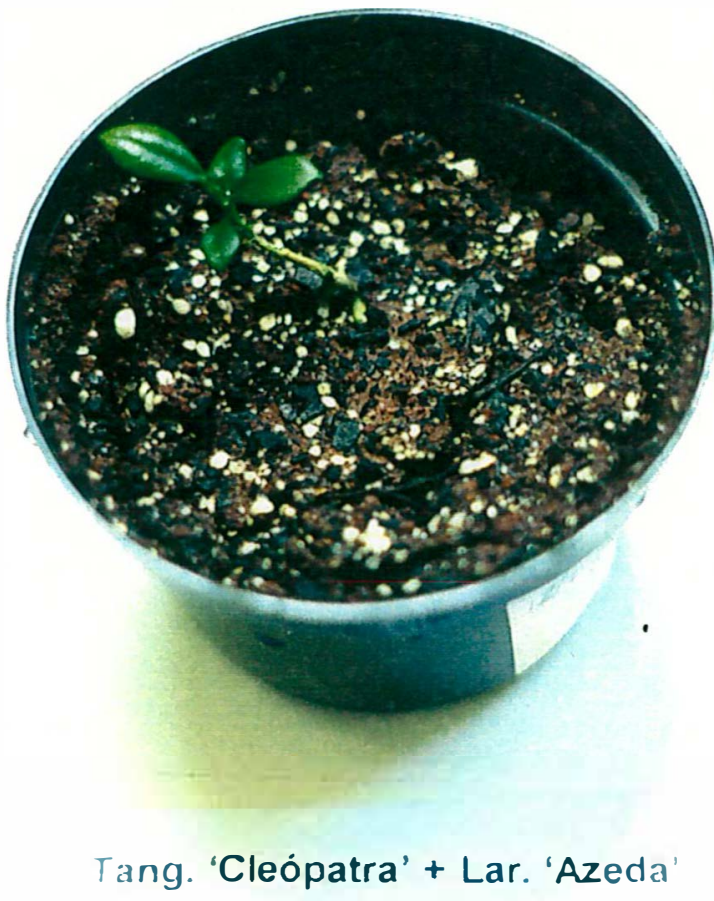

Figura 4. Híbrido somático de tangerina 'Cleópatra' e laranja 'Azeda' obtidos por fusão de protoplastos 
A morfologia foliar dos regenerantes mostrou-se intermediária à dos parentais. Os marcadores moleculares tipo RAPD confirmaram a hibridação entre a tangerina 'Cleópatra' e a laranja 'Azeda', como mostra a Figura 5. No estudo do polimorfismo molecular entre os parentais, para o 'kit' OPAA (Tecnologia Operon), observou-se bandas polimórficas em 13 dos 20 'primers' testados. Para a análise da hibridação somática utilizou-se os "primers" OPAA2, OPAA-4, OPAA-9, OPAA-11 e OPAA-16. O híbrido somático apresentou bandas polimórficas da tangerina 'Cleópatra' para os "primers" OPAA-2, OPAA11 e OPAA-16, enquanto as bandas polimórficas da laranja 'Azeda' apareceram no híbrido com o uso dos "primers" OPAA-4, OPAA-9 (duas bandas) e OPAA16 (Figura 5).

Os parentais do híbrido alcançado foram escolhidos por apresentarem características complementares potencialmente úteis a um bom porta-enxerto. Segundo Pompeú Junior (1991) e Davies \& Albrigo (1994), a tangerina 'Cleópatra' apresenta tolerância ao declínio, aos vírus da tristeza, da exocorte e da xiloporose, suporta muito bem o frio e é recomendada para plantios em solos argilosos e salinos, enquanto a laranja 'Azeda', tem um grande vigor no viveiro, alta tolerância à gomose, suporta muito bem a seca e o frio, também é tolerante ao declínio, resistente aos vírus da exocorte e da xiloporose, apresenta boa adaptabilidade aos solos, boa produtividade e boa qualidade de frutos. Uma desvantagem de cada parental isolado é a indução ao grande tamanho das copas, entretanto, um porta-enxerto tetraplóide tem a característica de induzir um menor tamanho da copa (Soost \& Cameron, 1975). Esta característica é de grande interesse à citricultura moderna, permitindo 0 adensamento dos pomares e reduzindo os custos de colheita dos frutos. 


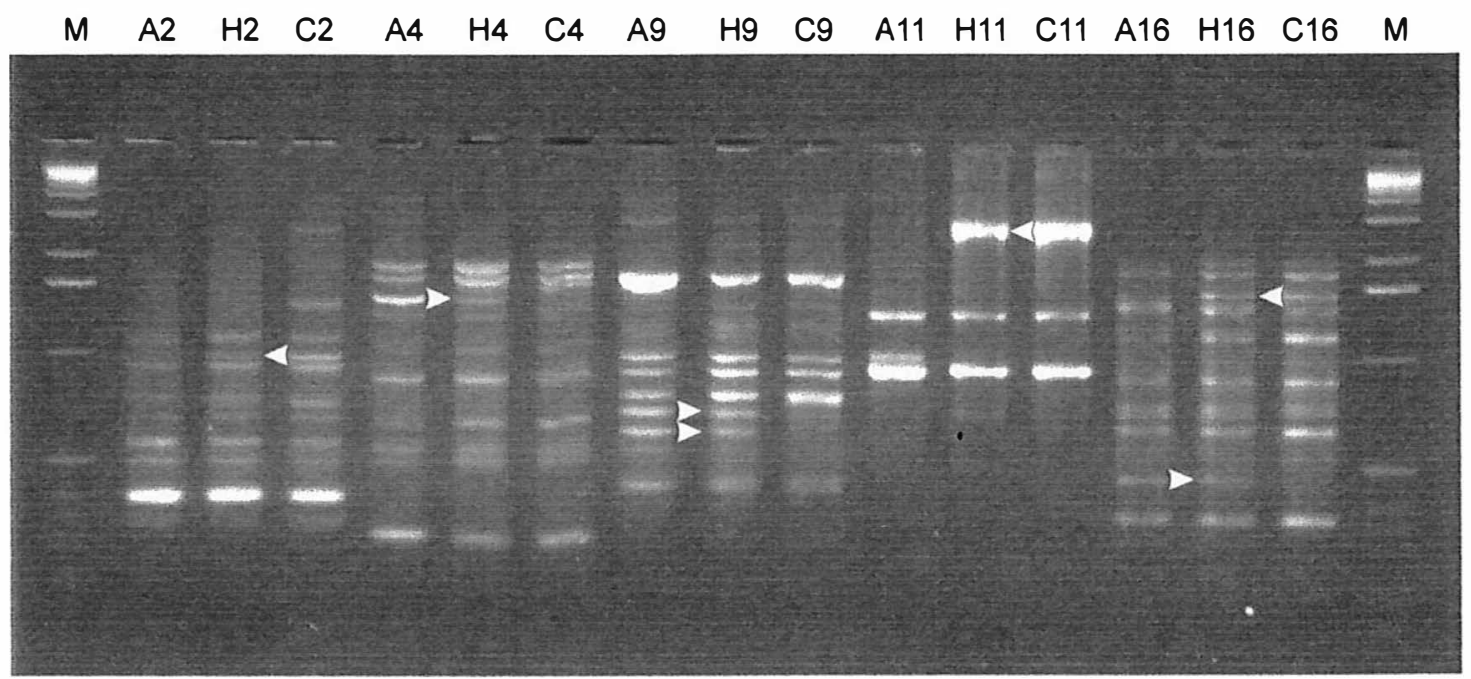

Figura 5. Padrões de RAPD do híbrido somático e seus parentais. $M=$ marcador de peso molecular (1kb). $A=$ laranja 'Azeda'; $H=$ híbrido somático; $\mathrm{C}=$ tangerina 'Cleópatra'. Os "primers" as série OPAA estão representados com os seus respectivos números ao lado de cada genótipo. As setas indicam as bandas que caracterizam a hibridação somática. 
Certamente esta combinação tem potencial para a diversificação dos porta-enxertos na citricultura brasileira, sendo uma alternativa para o portaenxerto hegemônico atual, o limão 'Cravo', após sua avaliação em experimentos no campo. Espera-se que a combinação tangerina 'Cleópatra' + laranja 'Azeda', em comparação ao limão 'Cravo', apresente tolerância ao declínio e à gomose, induza um menor porte da copa, resulte em frutos de qualidade e suporte bem a seca e o frio.

\subsection{Conclusões}

Os resultados obtidos neste experimento permitem-nos concluir:

1) Os protocolos de isolamento, fusão de protoplastos e regeneração de plantas foram eficientes para a obtenção do híbrido somático entre tangerina 'Cleópatra' e a laranja 'Azeda';

2) Os protocolos de análise da hibridação somática também adequaram-se perfeitamente ao estudo requerido;

3) O híbrido somático entre tangerina 'Cleópatra' e laranja 'Azeda' tem potencial para uso como porta-enxerto, sendo possivelmente tolerante ao declínio, induzir boa qualidade de frutos e menor porte da copa. Necessitase, entretanto, de estudos de campo para comprovarem as qualidades potenciais do híbrido somático conseguido. 


\section{CONCLUSÕES}

Os resultados obtidos nos experimentos permitem concluir que:

1) A resposta à indução da calogênese em laranja doce foi altamente influenciada pelas variedades, não podendo-se generalizar um meio de cultivo padrão para a formação de calos nas variedades de laranja doce;

2) A embriogênese somática mostrou-se bastante eficiente para todas as variedades estudadas, sendo, embora, mais expressivas em algumas que em outras. O carboidrato adicionado ao meio de cultivo que tendeu a produzir mais embriões foi a galactose para a maioria das variedades, embora outros carboidratos também tenham estimulado o processo embriogênico;

3) Para o isolamento de protoplastos, a solução enzimática composta por $1 \%$ celulase, $1 \%$ macerase e $0,2 \%$ pectoliase foi a mais adequada para todas as variedades de laranja doce estudadas. Entretanto, comparando-se com dados da literatura, observa-se um baixo rendimento na obtenção de protoplastos, indicando a necessidade do estudo de outros tratamentos que aumentem a eficiência de isolamento;

4) No experimento de fusão de protoplastos entre tangerina 'Cleópatra' e laranja 'Azeda' os protocolos de isolamento, fusão de protoplastos e regeneração de plantas mostraram-se adequados para a obtenção do híbrido somático; 
5) O híbrido somático produzido, dada a complementariedade de características entre os parentais, apresenta potencial para a diversificação dos porta-enxertos utilizados na citricultura, requerendo-se, no entanto, ensaios de campo para a comprovação de suas qualidades. 


\section{REFERÊNCIAS BIBLIOGRÁFICAS}

ANKER, S. Auxin-synthesis inhibition by sugars, notably by galactose. Acta Botanica Neerlandica, v.23, p.705-714, 1974.

BAJAJ, Y. P. S. Somatic hybridization - a rich source of genetic variability. In: BAJAJ, Y. P. S. (Ed.) Somatic hybridization in crop improvement I. Berlin: Springer-Verlag, 1994. p.3-32. (Biotechnology in Agriculture and Forestry, 27).

BEN-HAYYIM, G.; NEUMANN, H. Stimulatory effect of glycerol on growth and somatic embryogenesis in Citrus callus cultures. Zeitschrift füer Pflanzenphysiologie, v.110, p.331-337, 1983.

BUTTON, J. The effect of some carbohydrates on the growth and organization of Citrus ovular callus. Zeitschrift füer Pflanzenphysiologie, v.88, p.61-68, 1978.

CAMERON, J. W.; FROST, H. B. Genetics, breeding and nucellar embryony. In: REUTHER, W.; BATCHLOR, L. D.; WEBBER, H. J. (Ed.) The citrus industry. Berkeley: University of California Press, 1968. p.325-370.

CARNEIRO, V. T. C.; CONROI, T.; BARROS, L. M. G.; MATSUMOTO, K. Protoplastos: cultura e aplicações. In: TORRES, A. C.; CALDAS, L. S.; BUSO, J. A. (Ed.) Cultura de tecidos e transformaçæ̃o genética de plantas. Brasília: EMBRAPA, 1998. p.413-458

CID, L. P. B. Suspensão celular. In: TORRES, A. C.; CALDAS, L. S.; BUSO, J. A. (Ed.) Cultura de tecidos e transformação genética de plantas. Brasília: EMBRAPA, 1998. p.331-353. 
COCKING, E. C. A method for the isolation of plant protoplasts and vacuoles. Nature, v.187, p.962-963, 1960.

COLCLASURE, G. C.; YOPP, J. H. Galactose-induced ethylene evolution in mung bean hypocotyls: a possible mechanism for galactose retardation of plant growth. Physiologia Plantarum, v.37, p.298-302, 1976.

CRISTOFANI, M. Adaptação de metodologias de cultura de tecidos visando o melhoramento através de indução de mutações em Citrus sinensis (L.) Osbeck cv. Pera. Piracicaba, 1991. 185p. Dissertação (Mestrado) - Escola Superior de Agricultura "Luiz de Queiroz", Universidade de São Paulo.

DAVIES, F.; ALBRIGO, L. Citrus. Wallingford: CAB International, 1994. Cap.2, p.12-51: Taxonomy, cultivars and breeding.

DEJONG, A. J.; SCHMIDT, E. D. L.; DE VRIES, S. C. Early events in higher plant embryogenesis. Plant Molecular Biology, v.22, p.367-377, 1993.

DENG, X. X.; DENG, Z. A.; YE, X. R.; GAN, L.; ZHANG, W. C. Protoplast manipulation and breeding in citrus. Acta Agriculturae Sinica, v.2, p.129137, 1995.

DENG, X. X.; GROSSER, J. W.; GMITTER JUNIOR, F. G. Intergeneric somatic hybrid plants from protoplast fusion of Fortunella crassifolia cv. Meiwa with Citrus sinensis cv. Valencia. Scientia Horticulturae, v.45, p.55-62, 1992.

DOMINGUES, E. T. Bancos de germoplasma contribuem para a melhoria dos pomares. Informativo Agropecuário Coopercitrus, n.124, p.22-23, 1997. 
D'UTRA-VAZ, F. B., SANTOS, A. V. P.; MANDERS, G.; COCKING, E. C.; DAVEY, M. R.; POWER, J. B. Plant regeneration from leaf mesophyll protoplasts of the tropical woody plant, passionfruit (Passiflora edulis $\mathrm{fV}$ flavicarpa Degener.): the importance of the antibiotic cefotaxime in the culture medium. Plant Cell Reports, v.12, p.220-225, 1993.

EPSTEIN, E.; KOCHBA, J.; NEUMANN, H. Metabolism of indolacetic acid by embryogenic and non-embryogenic callus lines of 'Shamouti' orange (Citrus sinensis) Zeitschrift füer Pflanzenphysiologie, v.85, p. 263-268, 1977.

EVANS, D. A.; BRAVO, J. E. Protoplast isolation and culture. In: EVANS, D. A.; SHARP, W. R.; AMMIRATO, P. V.; YAMADA, Y. Handbook of plant cell culture: techniques for propagation and breeding. London: Collier Macmillan, 1983. v.1, cap.4, p.124-176.

FAO. FAOSTAT - statistics database . http://apps.fao.org. (15 abril 1999).

FERREIRA, M. E.; CALDAS, L. S.; PEREIRA, E. A. Aplicações da cultura de tecidos no melhoramento genético de plantas. In: TORRES, A. C.; CALDAS, L. S.; BUSO, J. A. (Ed.) Cultura de tecidos e transformação genética de plantas. Brasília: EMBRAPA, 1998. p.21-43.

FNP CONSULTORIA E COMÉRCIO. Agrianual 99: anuário estatístico da agricultura brasileira. São Paulo, 1999. 521p.

FREARSON, E. M.; POWER, J. B.; COCKING, E. C. The isolation, culture and regeneration of Petunia leaf protoplasts. Dev. Biol., v.33, p.130-137, 1973.

FUNDECITRUS. http://www.fundecitrus.com.br. (15 abril 1999). 
FUNGARO, M. H. P.; VIEIRA, M. L. C. Protoplastos de plantas: isolamento e regeneração. Ciência e Cultura, v.41, n.12, p.1151-1159, 1989.

GMITTER JUNIOR, F. G.; MOORE, G. A. Plant regeneration from undeveloped ovules and embryogenic calli of Citrus: embryo production, germination and plant survival. Plant Cell, Tissue and Organ Culture, v.6, p.139-147, 1986.

GMITTER JUNIOR, F. G.; GROSSER, J. W.; MOORE, G. A. Citrus. In: HAMMERSCHLAG, F. A.; LITZ R. E. (Ed.) Biotechnology of perennial fruit crops. Cambridge: University Press, 1992. cap.14, p.335-369.

GOLDMAN, M. H. S. Cultura de tecidos nucelares, isolamento e radiossensitividade de protoplastos de Citrus sinensis (L.) Osbeck Cv. Pera. Peracicaba, 1988. 127p. Dissertação (Mestrado) - Escola Superior de Agricultura "Luiz de Queiroz", Universidade de São Paulo.

GROSSER, J. W. Citrus scion and rootstock improvement via somatic hybridization. Acta Horticulturae, n.336, p.297-305, 1993.

GROSSER, J. W. In vitro culture of tropical fruit. In: VASIL, I. K.; THORPE, T. A. (Ed.) Plant cell and tissue culture. Dordrecht: Kluwer Academic, 1994. p.475-496.

GROSSER, J. W.; CHANDLER, J. L. Asseptic isolation of leaf protoplasts from Citrus, Poncirus, Poncirus $\times$ Citrus and Severinia for use in somatic hybridization experiments. Scientia Horticulturae, v.31, p.253-257, 1987.

GROSSER, J. W.; GMITTER JUNIOR, F. G. Protoplast fusion and citrus improvement. Plant Breeding Reviews, v.8, p.339-374, 1990a. 
GROSSER, J. W.; GMITTER JUNIOR, F. G. Somatic hybridization of Citrus with wild relatives for germoplasm enhancement and cultivar development. HortScience, v.25, n.2, p.147-151, 1990 b.

GROSSER, J. W.; GMITTER JUNIOR, F. G.; CHANDLER, J. L. Intergeneric somatic hybrid plants of Citrus sinensis cv. 'Hamlin' and Poncirus trifoliata cv. 'Frying Dragon'. Plant Cell Reports, v.7, p.5-8, 1988a.

GROSSER, J. W.; GMITTER JUNIOR, F. G.; CHANDLER, J. L. Intergeneric somatic hybrid from sexually incompatible woody species: Citrus sinensis and Severinia disticha. Theoretical and Applied Genetics., v.75, p.397-401, $1988 b$.

GROSSER, J. W.; GMITTER JUNIOR, F. G.; CHANDLER, J. L. Somatic hybrid plants from sexually incompatible woody species: Citrus reticulata and Citropsis gilletiana. Plant Cell Reports, v.8, p.656-659, 1990.

GROSSER, J. W.; MOORE, G. A.; GMITTER, JUNIOR, F. G. Interespecific somatic hybrid plants from the fusions of 'Key' lime (Citrus aurantifolia) with 'Valência' sweet orange (Citrus sinensis) protoplasts. Scientia Horticulturae, v.39, p.23-29, 1989.

GROSSER, J. W.; GMITTER JUNIOR, F. G.; LOUZADA, E. S.; CHANDLER, J. L. Production of somatic hybrid and autotetraploid breeding parents for seedless citrus development. HortScience, v.27, n.10, p.1125-1127, 1992a.

GROSSER, J. W.; GMITTER JUNIOR, F. G.; SESTO, F.; DENG, X. X. CHANDLER, J. L. Six new somatic citrus hybrids and their potential for cultivar improvement. Journal of the American Society for Horticultural Science, v.117, n.1, p.169-173, $1992 b$. 
GROSSER, J. W.; LOUZADA, E. S.; GMITTER JUNIOR, F. G.; CHANDLER,

J. L. Somatic hybridization of complementary citrus rootstocks: five new hybrids. HortScience, v.29, n.7, p.812-813, 1994.

GROSSER, J. W.; MOURÃO FILHO, F. A. A.; GMITTER JUNIOR, F. G.; LOUZADA, E. S.; JIANG, J.; BAERGEN, K.; QUIROS, A.; CABASSON, C.; SCHELL, J. L.; CHANDLER, J. L. Allotetraploid hybrids between citrus and seven related genera produced by somatic hybridization. Theoretical and Applied Genetics, v.92, p.577-582, 1996.

GROSSER, J. W.; JIANG, J.; MOURÃO FILHO, F. A. A.; LOUZADA, E. S.; BAERGEN, K; CHANDLER, J. L.; GMITTER JUNIOR, F. G. Somatic hybridization, na integral component of citrus cultivar improvement: I. scion improvement. HortScience, v.33, n.6, p.1057-1059, 1998a.

GROSSER, J. W.; JIANG, J.; LOUZADA, E. S.; CHANDLER, J. L.; GMITTER JUNIOR, F. G. Somatic hybridization, na integral component of citrus cultivar improvement: II. rootstock improvement. HortScience, v.33, n.6, p.10601061, $1998 \mathrm{~b}$.

GUERRA, M. P.; TORRES, A. C.; TEIXEIRA, J. B. Embriogênese somática e sementes sintéticas. In: TORRES, A. C.; CALDAS, L. S.; BUSO, J. A. (Ed.) Cultura de tecidos e transformação genética de plantas. Brasília: EMBRAPA, 1998. p.533-568.

HIDAKA, T. A 'shuttle callus system' - application of tissue culture in citrus. Acta Horticulturae, v.392, p.39-48, 1995.

HIDAKA, T.; KAJIURA, I. Plantlet differentiation from callus protoplasts induced from Citrus embryo. Scientia Horticulturae, v.34, p.85-92, 1988. 
HIDAKA, T.; OMURA, M. Regeneration of somatic hybrid plants obtained by electrical fusion between satsuma mandarin (Citrus unshiu) and rough lemon (C. jambhiri) or yuzu (C. junos). Japanese Journal of Breeding, v.42, n.1, p.79-89, 1992.

HOISINGTON, D.; KHAIRALLAH, M.; GONZÁLEZ-DE-LEÓN. Laboratory protocols: CIMMYT Applied Molecular Genetics Laboratory. 2.ed. Mexico: CIMMYT, 1994. 88p.

JIMÉNEZ, V. M. El cultivo de protoplastos cítricos y su potencial para el mejoramiento genético. Agronomía Costarricense, v.20, n.2, p.187-204, 1996.

JONGKEE, K; GROSS, K. C.; SOLOMOS, T. Characterization of the stimulation of ethylene production by galactose in tomato fruit. Plant Physiology, v.85, p.804-807, 1987.

JUMIN, H. B.; NITO, N. Plant regeneration via embryogenesis from protoplasts of six plant species related to Citrus. Plant Cell Reports, v.15, p.332-336, 1996a.

JUMIN, H. B.; NITO, N. Plant regeneration via somatic embryogenesis from protoplasts of Uganda cherry orange (Citropsis schweinfurthii). Plant Cell Reports, v.15, p.754-757, 1996b.

KAO, K. N.; MICHAYLUK, M. R. A method for high-frequency intergeneric fusion of plant protoplasts. Planta, v.115, p.355-367, 1974.

KOBAYASHI, S.; OHGAWARA, T. Production of somatic hybrid plants through protoplast fusion in citrus. Japan Agricultural Research Quarterly, v.22, n.3, p.181-188, 1988. 
KOBAYASHI, S.; UCHIMIYA, H.; IKEDA, I. Plant regeneration from 'Trovita'orange protoplasts. Japanese Journal of Breeding, v.33, n.2, p.119-122, 1983.

KOBAYASHI, S.; IKEDA, I.; NAKATANI, N. Induction of nucellar callus from orange (Citrus sinensis Osb.) ovules, and uniformity of regenerated plants. Bulletin of the Fruit Tree Research Station, v.5, p.43-54, 1984.

KOBAYASHI, S.; IKEDA, I.; UCHIMIYA, H. Condition for high frequency embryogenesis from orange (Citrus sinensis Osb.) protoplasts. Plant Cell, Tissue and Organ Culture, v.4, p.149-159, 1985.

KOBAYASHI, S.; FUJIWARA, K.; OIYAMA, T.; OHGAWARA, T.; ISHII, S. Somatic hybridization between navel orange and 'Murcott' tangor. In: INTERNATIONAL CITRUS CONGRESS, 6, 1988. Proceedings. 1988a. v.1, p.135-140.

KOBAYASHI, S.; OHGAWARA, T.; FUJIWARA, K.; OIYAMA, T. Analysis of cytoplasmic genomes in somatic hybrids between navel orange (Citrus sinensis Osb.) and 'Murcott' tangor. Theoretical and Applied Genetics, v.82, n.1, p.6-10, 1991 a.

KOBAYASHI, S.; OHGAWARA, T.; OHGAWARA, E.; OIYAMA, T. ; ISHII, S. A somatic hybrid plant obtained by protoplast fusion between navel orange (Citrus sinensis) and satsuma mandarin (C. unshiu). Plant Cell, Tissue and Organ Culture, v.14, n.2, p.63-69, 1988b.

KOBAYASHI, S.; OHGAWARA, T.; SAITO, W.; NAKAMURA, Y.; SHIMIZU, J. Fruit caracteristics and pollen fertility of citrus somatic hybrids. Journal of the Japanese Society for Horticultural Science, v.64, n.2., p.283-289, 1995. 
KOBAYASHI, S.; OIYAMA, I.; YOSHINAGA, K.; OHGAWARA, T.; ISHII, S. Fertility in an intergeneric somatic hybrid plant of Rutaceae. HortScience, v.26, p.207, $1991 b$.

KOCHBA, J.; SPIEGEL-ROY, P. Effect of culture media on embryoid formation from ovular callus of 'Shamouti' orange (Citrus sinensis). Journal of Plant Breeding, v.69, p.156-162, 1973.

KOCHBA, J.; SPIEGEL-ROY, P. The effects of auxins, cytokinins and inhibitors on embryogenesis in habituated ovular callus of the 'Shamouti' orange (Citrus sinensis). Zeitschrift füer Pflanzenphysiologie, v.81, p.283-288, 1977.

KOCHBA, J.; SPIEGEL-ROY, P.; SAFRAN, H. Adventive plants from ovules and nucelli in Citrus. Planta, n.106, p.237-245, 1972.

KOCHBA, J.; SPIEGEL-ROY, P.; NEUMANN, H.; SAAD, S. Stimulation of embryogenesis in citrus ovular callus by ABA, ethephon, CCC and alar and its supression by $\mathrm{GA}_{3}$. Zeitschrift füer Pflanzenphysiologie, v.89, p.427432, 1978.

KOCHBA, J.; SPIEGEL-ROY, P.; NEUMANN, H.; SAAD, S. Effect of carbohydrates on somatic embryogenesis in subcultured nucellar callus of Citrus cultivars. Zeitschrift füer Pflanzenphysiologie, v.105, p.359-368, 1982.

KRUL, W. R.; COLClasuRE, G. C. Effect of galactose and other monosaccharides on IAA movement in bean hypocotyl segments. Physiologia Plantarum, v.41, p.246-253, 1977.

KUNITAKE, H.; MII, M. Somatic Embryogenesis in Citrus species. In: BAJAJ, Y. P. S. (Ed.) Somatic Embryogenesis and Synthetic Seed I. Berlin: 
Springer-Verlag, 1995. p.280-298. (Biotechnology in Agriculture and Forestry, 30).

KUNITAKE, H.; KAGAMI, H.; MII, M. Somatic embryogenesis and plant regeneration from protoplasts of 'Satsuma' mandarin (Citrus unshiu Marc.). Scientia Horticulturae, v.47, p.27-33, 1991.

LATADO, R. R. Hibridação somática entre limão Cravo (Citrus limonia Osbeck) e tangerina Cleópatra (Citrus reshni Hort.). Piracicaba, 1998. 146p. Tese (Doutorado) - Escola Superior de Agricultura "Luiz de Queiroz", Universidade de São Paulo.

LING, J. T.; NITO, N.; IWAMASA, M. Plant regeneration from protoplasts of Calamondin (Citrus madurensis Lour.). Scientia Horticulturae, v.39, p.325$333,1989$.

LING, J. T.; NITO, N.; IWAMASA, M.; KUNITAKE, H. Plant regeneration from protoplast isolated from embriogenic callus of Satsuma. HortScience, v.25, n.8, p.970-972, 1990.

LITZ, R. E.; GRAY, D. J. Organogenesis and somatic embryogenesis. In: HAMMERSCHLAG, F. A.; LITZ R. E. (Ed.) Biotechnology of perennial fruit crops. Cambridge: University Press, 1992. cap.14, p.3-34.

LORENZO, J. C.; GARCÍA, G.; ESCALONA, M.; DAQUINTA, M. A.; CASTILLO, R.; FUNDORA, Z.; BORROTO, C. G. Embriogenesis somatica in vitro en mandarina Cleopatra (Citrus reshni Hort. Ex Tan.). Centro Agrícola, v.21, n.3, p.85-91, 1994.

LOUZADA, E. S.; GROSSER, J. W.; GMITTER JUNIOR, F. G.; NIELSEN, B.; CHANDLER, J. L. Eight new somatic hybrid citrus rootstocks with potencial for improved disease resistence. HortScience, v.27, n.9, p.1033-1036, 1992. 
MARETZKI, A.; THOM, M. Characteristics of a galactose-adapted sugarcane cell line grown in suspension culture. Plant Physiology, v.61, p.544-548, 1978.

MASUDA, Y. Auxin-induced cell elongation and cell wall changes. Botanical Magazine, v.103, p.345-370, 1990.

MENDES-DA-GLÓRIA, F. J. Hibridação somática entre laranja 'Caipira' e limão 'Cravo' através de fusão de protoplastos. Piracicaba, 1998. 78p. Dissertação (Mestrado) - Escola Superior de Agricultura "Luiz de Queiroz", Universidade de São Paulo.

MIRANDA, M.; MOTOMURA, T.; IKEDA, F.; OHGAWARA, T.; SAITO, W.; ENDO, T.; OMURA, M.; MORIGUCHI, T. Somatic hybrids obtained by fusion between Poncirus trifoliata (2x) and Fortunella hindsii (4x) protoplasts. Plant Cell Reports, v.16, p.401-405, 1997.

MOORE, G. A. Factors affecting in vitro embryogenesis from underveloped ovules of mature Citrus fruit. Journal of the American Society for Horticultural Science, v.110, p.66-70, 1985.

MOREIRA, C. S.; MOREIRA, S. História da citricultura no Brasil. In: RODRIGUEZ, O.; VIÉGAS, F.; POMPEU JUNIOR, J.; AMARO, A. A. (Ed.) Citricultura brasileira. Campinas: Fundação Cargill, 1991. p.1-21.

MOREIRA, C. S.; PIO, R. M. Melhoramento de citros. In: RODRIGUEZ, O.; VIÉGAS, F.; POMPEU JUNIOR, J.; AMARO, A. A. Ciêricultura Brasileira. Campinas: Fundação Cargill, 1991. p.116-152.

MORIGUCHI, T.; HIDAKA, T.; OMURA, M.; MOTOMURA, T.; AKIHAMA, T. Genotype and parental combination influence efficience of cybrid induction in Citrus by electrofusion. HortScience, v.31, n.2, p.275-278, 1996. 
MORIKAWA, H.; YAMADA, Y. Protoplast fusion. In: FOWLER, M. W.; WARREN, G. S.; MOO-YOUNG, M. (Ed.). Plant Biotechnology: comprehensive biotechnology. Oxford: Pergamon Press, 1992. p.199-222.

MOURÃO FILHO, F. A. A. Protoplast fusion for rootstock and scion improvement with emphasis on wide hybridization. Gainesville, 1995. 152p. Thesis (PhD) - University of Florida.

MOURÃO FILHO, F. A. A.; GMITTER JUNIOR, F. G.; GROSSER, J. W. New tetraploid breeding parents for triploid seedless citrus cultivar development. Fruit Varieties Joumal, v.50, n.2, p.76-80, 1996.

MOURÃO FILHO, F. A. A.; GROSSER, J. W. Callus induction from Citrus relatives: na alternative souce of protoplasts for somatic hybridization experiments. Proceedings of the Florida State for Horticultural Society, v.105, p.52-56, 1992.

MOURÃO FILHO, F. A. A.; GROSSER, J. W.; GMITTER JUNIOR, F. G. In vitro Citrus breeding for scion improvement. HortScience, v.29, n.5, p.482, 1994a.

MOURÃO FILHO, F. A. A.; GROSSER, J. W.; GMITTER JUNIOR, F. G. Production of seven new intergeneric somatic hybrids for Citrus rootstock improvement. HortScience, v.29, n.5, p.482-483, 1994b.

MURASHIGE, T.; TUCKER, D. Growth factors requirements of Citrus tissue culture. In: FIRST CITRUS SYMPOSIUM, 1., Riverside, 1969. Proceedings of First Citrus Symposium. Riverside: University of California, 1969. p.1155-1161.

NONINO, E. A. Variedades de laranjas para fabricação de sucos. Laranja, v.16, n.1, p.119-132, 1995. 
OCHATT, S. J.; POWER, J. B. Plant regeneration from cultured protoplasts of higher plants. In: FOWLER, M. W.; WARREN, G. S.; MOO-YOUNG, M. (Ed.) Plant biotechnology: comprehensive biotechnology. Oxford: Pergamon Press, 1992. p.99-127.

OHGAWARA, T.; KOBAYASHI, S.; ISHII, S.; YOSHINAGA, K.; OIYAMA, T. Somatic hybridization in Citrus: navel orange (Citrus sinensis Osb.) and grapefruit (C. Paradisi Macf.). Theoretical and Applied Genetics, v.78, n.5, p.609-612, 1989.

OHGAWARA, T.; KOBAYASHI, S.; ISHII, S.; YOSHINAGA, K.; OIYAMA, I. Fertile fruit trees obtained by somatic hybridization: Navel orange (Citrus sinensis) and Troyer citrange (C. Sinensis $\times$ Poncirus trifoliata). Theoretical and Applied Genetics, v.81, p.141-143, 1991.

OHGAWARA, T.; KOBAYSAHI, S.; OHGAWARA, E.; UCHIMIYA, H.; ISHII, S. Somatic hybrid plants obtained by protoplast fusion between Citrus sinensis and Poncirus trifoliata. Theoretical and Applied Genetics, v.71, p.1-4, 1985.

OLIVEIRA, R. P. Cultura de calos, células em suspensão e protoplastos de porta-enxertos de citros. Piracicaba, 1993. 117p. Dissertação (Mestrado) Escola Superior de Agricultura "Luiz de Queiroz", Universidade de São Paulo.

OLIVEIRA, R. P.; MENDES, B. M. J.; TULMANN NETO, A. Determinação de metodologia para $\mathrm{O}$ isolamento de protoplastos de tangerina 'Cleópatra' (Citrus reshni Hort.). Scientia Agricola, v.52, n.1, p.38-42, 1995.

OLIVEIRA, R. P.; MENDES, B. M. J.; TULMANN NETO, A. Obtenção e cultura de calos nucelares de limão Cravo, tangerina Cleópatra e Poncirus trifoliata. Revista Brasileira de Fisiologia Vegetal, v.6, n.2, p.115-119, 1994. 
PARROT, W. A.; MERKLE, S. A.; WILLIAMS, E. G. Somatic embryogenesis: potencial for use in propagation and gene transfer systems. In: MURRAY, D. R. (Ed.) Advanced methods in plant breeding and biotecnology. Wallinford: CAB International, p.158-200, 1991.

POMPEU JUNIOR, J. Porta-enxertos. In: RODRIGUEZ, O.; VIÉGAS, F.; POMPEU JUNIOR, J.; AMARO, A. A. (Ed.) Citricultura brasileira. Campinas: Fundação Cargill, 1991. p.265-280.

REDDY, C. S.; HASAN, M. V.; JAGDISH, C. A. Role of plant tissue and cell culture in crop improvement. In: FAROOK, S. A.; KHAN, I. A. (Ed.) Recents advances in genetics and cytogenetics. Kothi: Premier Publ., 1989. p.431446.

SAITO, W.; OHGAWARA, T.; SHIMIZU, J.; ISHII, S. Acid citrus somatic hybrids between sudachi (Citrus sudachi Hort. ex Shirai) and lime (C. aurantifolia Swing.) produced by eletrofusion. Plant Science, v.77, p.125-130, 1991.

SAITO, W.; OHGAWARA, T.; SHIMIZU, J.; ISHII, S.; KOBAYASHI, S. Citrus cybrid regeneration following cell fusion between nucellar cells and mesophyll cells. Plant Science, v.88, p.195-201, 1993.

SIM, G. E.; LOH, C. S.; GOH, C. L. Direct somatic embryogenesis from protoplasts of C. mitis Blanco. Plant Cell Reports, v.7, p.418-20, 1988.

SOOST, R. K.; CAMERON, J. W. Citrus. In: JANICK, J.; MOORE, J. N. (Ed.): Advances in Fruit Breeding. West Lafayete: Purdue University Press, 1975, p.507-540.

STARRANTINO, A.; RUSSO, F. Seedlings from undeveloped ovules of ripe fruits of polyembryonic citrus cultivars. HortScience, v.15, n.3, p.296-297, 1980. 
SWINGLE, W. T.; REECE, P. C. The botany of citrus and its relatives. In: REUTHER, W.; WEBBER, H. J.; BATCHELOR, L. D. (Ed.). The Citrus Industry. Berkeley: University of California Press, 1967. vol.1, p.190-430.

TORRES, A. C.; CALDAS, L. S.; BUSO, J. A. Cultura de tecidos e transformação genética de plantas. Brasília: EMBRAPA, 1998. 2 v.

TUSA, N.; GROSSER, J. W.; GMITTER JUNIOR, F. G. Plant regeneration of 'Valencia' sweet orange, 'Femminello' lemon, and the interspecific somatic hybrid following protoplast fusion. Journal of the American Society for Horticultural Science, v.115, n.6, p.1043-1046, 1990.

TUSA, N.; GROSSER, J. W.; GMITTER JUNIOR, F. G.; LOUZADA, E. S. Production of tetraploid somatic hybrid breeding parents for use in lemon cultivar improvement. HortScience, v.27, n.5, p.445-447, 1992.

VARDI, A.; GALUN, E. Recent advances in protoplast culture of horticultural crops: Citrus. Scientia Horticulturae, v.37, p.217-230, 1988.

VARDI , A.; GALUN, E. Isolation and culture of citrus protoplasts. In: BAJAJ, Y. P. S., (Ed.). Plant protoplasts and genetic engeneering I. Berlin: Springer-Verlag, 1989. cap.2-3, p. 147-159. (Biotechnology in Agriculture and Forestry, 8).

VARDI, A.; BLEICHMAN, S.; AVIV, D. Genetic transformation of citrus protoplasts and regeneration of transgenic plants. Plant Science, v.69, p.199-206, 1990.

VARDI, A.; BREIMAN, A.; GALUN, E. Citrus cybrids: production of donorrecipient protoplast fusion and verification by mitochondrial DNA restriction profiles. Theoretical and Applied Genetics, v.75, p.51-58, 1987. 
VARDI, A.; HUTCHISON, D. J.; GALUN, E. A protoplast-to-tree system in Microcitrus based on protoplasts derived from a sustained embryogenic callus. Plant Cell Reports, v.5, p.412-414, 1986.

VARDI, A.; SPIEGEL-ROY, P.; GALUN, R. Citrus cell culture: isolation of protoplasts, plating densities, effect of mutagens and regeneration of embryos. Plant Science Letters, v.4, p.231-236, 1975.

VARDI, A.; SPIEGEL-ROY, P.; GALUN, E. Plant regeneration from citrus protoplasts: variability in methodological requeriments among cultivars and species. Theoretical and Applied Genetics, v.62, p.171-176, 1982.

VARDI, A.; GONEN, P. A.; SHANI, S. F.; BLEICHMAN, S.; GALUN, E. Protoplast fusion mediated transfer of organelles form Microcitrus into Citrus and regeneration of novel alloplasmic trees. Theoretical and Applied Genetics, v.78, p.741-747, 1989.

VIEIRA, M. L. C. Estudo citotaxonômico de espécies brasileiras do gênero Stylosanthes Sw. Piracicaba, 1988. 135p. Tese (Doutorado) - Escola Superior de Agricultura "Luiz de Queiroz", Universidade de São Paulo.

VU, J. C. V.; NIEDZ, R. P.; YELENOVSKY, G. Glycerol stimulation of chlorophyll synthesis, embryogenesis, and carboxylation and sucrose metabolism enzymes in nucellar callus of 'Hamlin' sweet orange. Plant Cell, Tissue and Organ Culture, v.33, p.75-80, 1993.

WILLIAMS, E. G.; MAHESWARAN, G. Somatic embryogenesis: factors influencing behaviour of cells as na embryogenic group. Annals of Botany, v.57, p.443-462, 1986. 
YAMAMOTO, R.; INOUHE, M.; MASUDA, Y. Galactose inhibition of auxininduced growth of mono- and dicotyledonous plants. Plant Physiology, v.86, p.1223-1227, 1988.

YEUNG, E. C. Structural and developmental patterns in somatic embryogenesis. In: THORPE, T. A. (Ed.) In vitro embryogenesis in plants. Dordrecht: Kluwer Academic, 1995. p.205-247.

ZANOL, G. C.; OLIVEIRA, R. P.; SOARES FILHO, W. S.; SOUZA, G. S. Ajuste de metodologias para a obtenção de calos nucelares embriogênicos e cultivo in vitro de "seedlings"de citros. In: II ENCONTRO BRASILEIRO DE BIOTECNOLOGIA VEGETAL, Gramado, 1997. Resumos. Gramado, 1997. p.178.

ZIMMERMANN, J. L. Somatic embryogenesis: a model for early development in higher plants. Plant Cell, v.5, p.1411-1423, 1993.

ZIMMERMANN, V. Electric-field mediated fusion and related electrical phenomena. Biochimica ef Biophysica Acta, n.694, p.227-277, 1982.

ZIMMERMANN, V.; SCHEVRICH, P. High frequency fusion of plant protoplasts by electric fields. Planta, n.151, p.26-32, 1981. 